\title{
The Early Branching Group of Orbiniida Sensu Struck et al., 2015: Parergodrilidae and Orbiniidae
}

\author{
Miguel A. Meca ${ }^{1, *(D)}$, Anna Zhadan ${ }^{2}\left(\mathbb{D}\right.$ and Torsten H. Struck ${ }^{3}$ \\ 1 Department of Natural History, University Museum of Bergen, University of Bergen, Postboks 7800, \\ 5020 Bergen, Norway \\ 2 N.A. Pertsov White Sea Biological Station, Biological Faculty, M.V. Lomonosov Moscow State University, \\ Leninskie Gory 1-12, 119234 Moscow, Russia; azhadan@wsbs-msu.ru \\ 3 Frontiers of Evolutionary Zoology Research Group, Natural History Museum, University of Oslo, \\ 0562 Oslo, Norway; t.h.struck@nhm.uio.no \\ * Correspondence: Miguel.Meca@uib.no
}

check for updates

Citation: Meca, M.A.; Zhadan, A.; Struck, T.H. The Early Branching Group of Orbiniida Sensu Struck et al., 2015: Parergodrilidae and Orbiniidae. Diversity 2021, 13, 29. https://doi.org/10.3390/d13010029

Received: 17 November 2020 Accepted: 21 December 2020 Published: 13 January 2021

Publisher's Note: MDPI stays neutral with regard to jurisdictional clai$\mathrm{ms}$ in published maps and institutional affiliations.

Copyright: (C) 2021 by the authors. Licensee MDPI, Basel, Switzerland. This article is an open access article distributed under the terms and conditions of the Creative Commons Attribution (CC BY) license (https:// creativecommons.org/licenses/by/ $4.0 /)$.

\begin{abstract}
This review addresses the state of the art of the systematics and the improvements in the biology, ecology and species diversity of the two annelid taxa Parergodrilidae and Orbiniidae, the early branching group of Orbiniida sensu Struck et al., 2015 according to molecular studies. An effort to identify gaps of knowledge is given to understand the distribution, dispersal and the diversity Parergodrilidae and Orbiniidae hold, as well as to give several directions for future research. Parergodrilidae is a taxon of interstitial annelids constituted by the terrestrial Parergodrilus heideri (monotypic genus up to date), reported throughout Europe but also in Korea and North America, and the genus Stygocapitella, which includes eleven species from the upper shore of sandy beaches distributed along Europe and other regions of the world. Orbiniidae contains more than 200 described species spread over 20 valid genera, varying in size from a few millimeters up to $30 \mathrm{~cm}$, distributed globally and living in a wide variety of soft bottoms. Improving the knowledge on these two sister-taxa is crucial for the understanding of the evolution to interstitial forms by progenesis in Annelida.
\end{abstract}

Keywords: biodiversity; biology; distribution; diversity; ecology; phylogeny; taxonomy

\section{Introduction}

While abounding the concepts of Sedentaria and Errantia, Fauchald [1] erected Orbiniida comprising Orbiniidae, Paraonidae and Questidae due to the lack of antennae and palps and possession of an eversible pharynx and biramous parapodia with simple chaetae. All three taxa had before been regarded as part of Sedentaria, e.g., [2-4]. Based on their morphological-cladistic analyses, Rouse and Fauchald [5] regarded all three taxa also as a monophyletic group within Scolecida. Molecular data placed Questidae within Orbiniidae but Paraonidae as probably more closely related to Cirratulida see [6,7]. Struck et al. [8] re-erected the groups Sedentaria and Errantia but with changes in their taxon composition; Orbiniidae was in this study part of Errantia. However, a following study showed that this was caused by a single erroneously assigned paralogous gene and instead Orbiniidae had to be placed in Sedentaria [9]. Subsequent phylogenomic studies generally found Orbiniidae as sister to or being part of the sistergroup to the remaining Sedentaria $[7,10,11]$.

As part of this placement within Sedentaria, Orbiniida has been recognized again, but with a different taxon composition [12]. Besides Orbiniidae (including Questidae), it now comprises several interstitial annelid groups, each of which were at one point assigned to the polyphyletic Archiannelida (see [7,13] and the article on interstitial annelids in this issue for a more detailed discussion). Namely, these taxa belonging to Orbiniida are Parergodrilidae, Dinophilidae, Diurodrilus, Apharyngtus and Nerillidae [12]. According to the authors, the evolution of these groups is best explained by recurrent independent events of 
progenesis, which most likely happened in an orbiniid-like ancestor. However, depending on the analytical strategy applied some recent analyses showed that Dinophilidae are placed outside Orbiniida and together with Lobatocerebrum as sister to Pleistoannelida, while independent of the strategy Parergodrilidae, Apharyngtus and Diurodrilus remained closely related to Orbiniidae [11]. Nerillidae were not included in the analyses and, hence, no data have been provided yet excluding them from Orbiniida. Of all interstitial taxa possibly placed within Orbiniida, the close relationship of Parergodrilidae and Orbiniidae is the best supported by molecular data [12,14-21].

In conclusion, Orbiniida as of today consists of Orbiniidae, Parergodrilidae, Nerillidae, Apharyngtus and Diurodrilus as well as possibly Dinophilidae [7,10-12]. However, for reasons of consistency all interstitial taxa except Parergodrilidae are treated in the article on interstitial annelids in this issue. Here, we will review the recent advances of our knowledge about the biology, ecology, taxonomy and species diversity as well as identify relevant gaps of knowledge to understand the species diversity, distribution and dispersal of Orbiniidae and Parergodrilidae.

\section{Parergodrilidae Reisinger, 1925}

Parergodrilidae is a taxon of small-sized, stout annelids of 0.8 to $2.8 \mathrm{~mm}$ body length to 0.1 to $0.25 \mathrm{~mm}$ body width, which until very recently consisted of only two species in two genera, namely Stygocapitella subterranea Knöllner, 1934 and Parergodrilus heideri Reisinger, 1925. The latter is a terrestrial polychaete, while the former lives in the transition zone from the marine environment to the terrestrial habitat. Parergodrilidae was in its first description placed within Archiannelida [22], while others regarded them as clitellates [23]. Moreover, before Karling [24] it was not recognized that S. subterranea and P. heideri constitute one taxon and S. subterranea was regarded as closely related to Capitellidae [25]. After Karling [24] Parergodrilidae was often considered as closely related to Ctenodrilidae but without the indication of morphological autapomorphies, e.g., [1,26]. Alternatively, a closer relationship to Hrabeiella periglandulata, another terrestrial polychaete species, has been suggested [27]. However, none of the relationships was strongly supported by morphological data, e.g., [28-30]. Accordingly, the morphological-cladistic analyses by Rouse and Fauchald [5] found Parergodrilidae as in certae sedis within polychaetes. Nowadays, however, as mentioned above molecular data unequivocally support a sistergroup relationship to Orbiniidae.

\subsection{Parergodrilus Reisinger, 1925}

Parergodrilus heideri was first described from leaf litter samples in Austrian beech forests by Reisinger [22] (Figure 1D). It had been assumed for some time that the species is restricted to this kind of habitat, specifically the leaf-litter, organic soil layer of montane beech forests, which is humid, but not water-logged, and slightly alkaline to moderately acid, e.g., [30-35]. However, the species has now been recorded from different habitats including different forest types like spruce and maple forests, low-land, wetter and more acidic ones, e.g., [31,36-40]. Hence, the original restricted distribution could reflect more biases in sampling than restriction of the species. Nonetheless, the species seems to occur only in the humus-rich upper layer of soil, often within the first three to six centimeters.

Interestingly, there is a strong difference in the sex ratio favoring females with ratios of $1: 8$ to $1: 170$ [28-30,33,41]. Accordingly, in the beginning only female specimens were found and considered to be hermaphrodites [22]. However, later these were recognized as females and $P$. heideri is generally regarded as being gonochoristic, while some doubts remain about the latter conclusion [24,33,42-45]. Different reasons for this pronounced sex ratio imbalance have been suggested, which include differences in behavior, longevity and size [33]. In Austria, males have only been found during the summer months, while in a German beech forest, mature females with vitellogenic oocytes and spermatozoa in the receptacula seminis have been found throughout the year $[33,45]$. Hence, it is uncertain if reproduction occurs throughout the year, only during the summer period 
or only insemination occurs during the summer months with spermatozoa stored in the receptacula seminis throughout the year. Eggs are deposited in cocoons, which are attached to the substrate. The eight to ten day-long development is direct and four-chaetiger stages of $60-80 \mu \mathrm{m}$ body length hatch from the cocoon. Early cleavage resembles an unequal spirale cleavage [33].

A

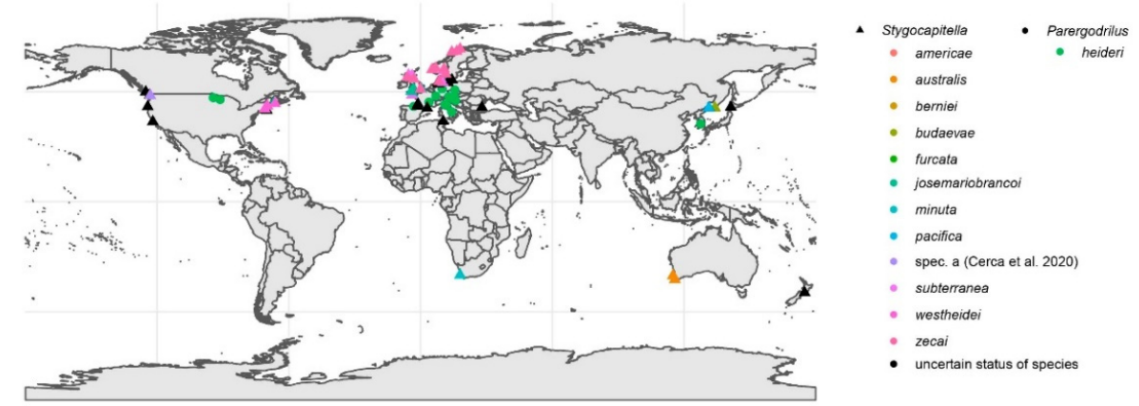

B
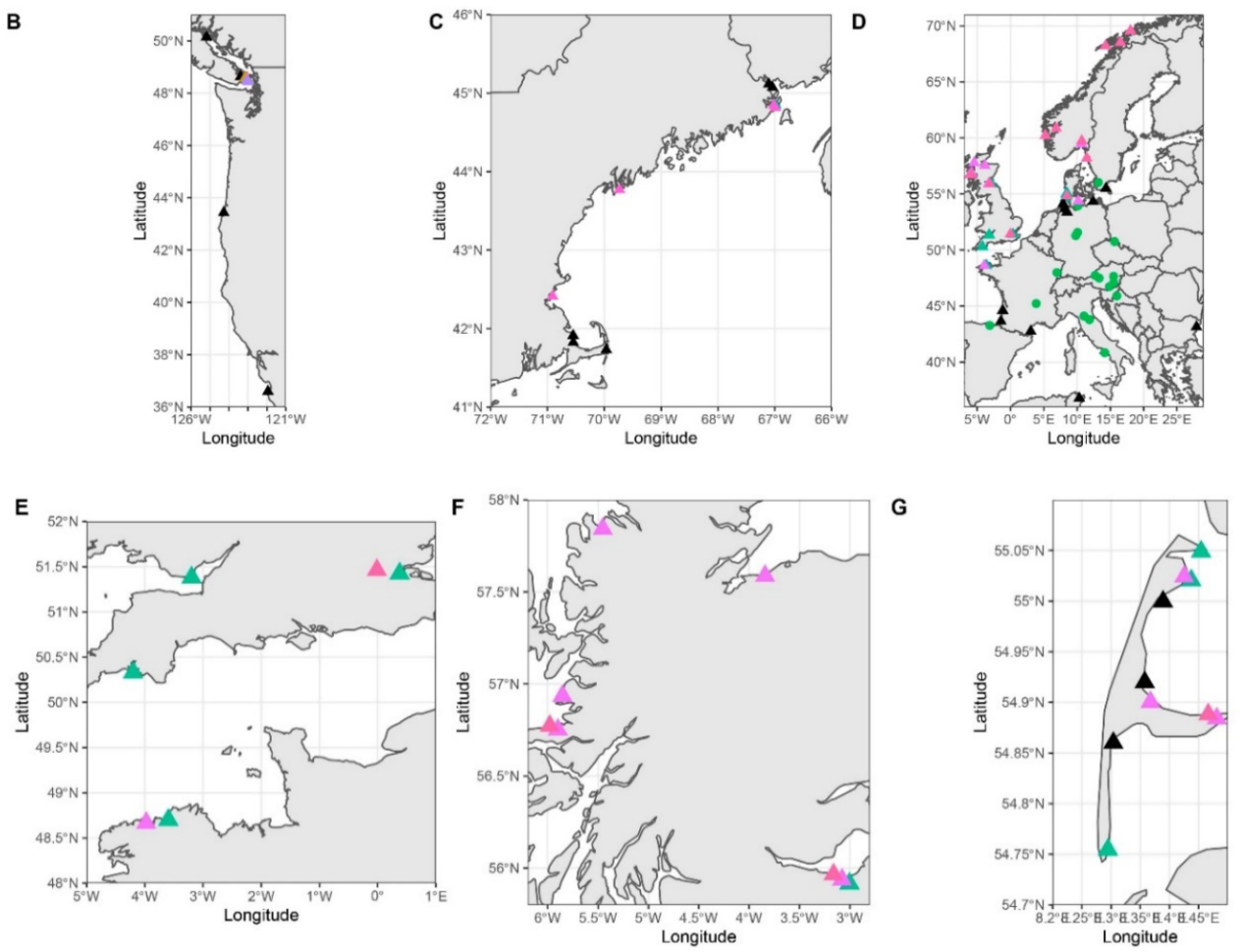

H

।
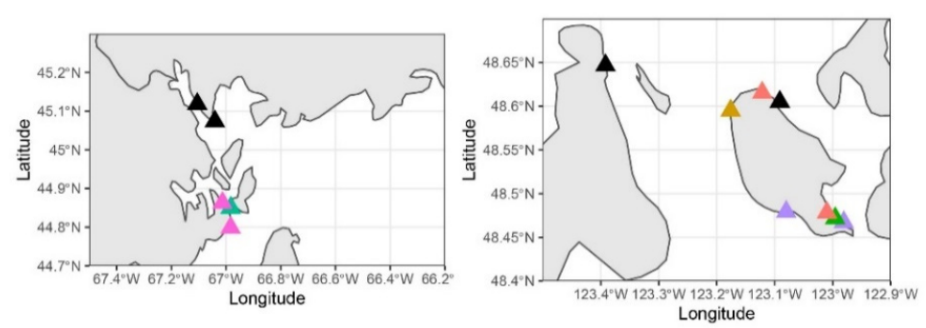

Figure 1. Map of known records for both Stygocapitella (triangles) and Parergodrilus (circles). Color codes for the different species are shown in the upper right legend. Records of Stygocapitella. with unknown species affiliation (see text) are shown as black triangles. (A) Whole world; (B) North America Pacific coast; (C) North America Atlantic coast; (D) Europe; (E) The Channel; (F) Scottish coast; (G) North Sea island Sylt; (H) Passamaquoddy Bay and adjacent waters; (I) San Juan Island. Maps were generated using the R packages tidyverse, ggplot2, sf, rnaturalearth, rnaturalearthdata, rnaturalearthhires, ggmap and ggpubr. 
In P. heideri, males possess ten chaetigers (Figure 2), while females have only eight. Both also have an additional achaetigerous segment after the peristomium [33]. Each chaetigerous segment has a pair of bundles, which contain two very simple, oligochaetelike chaetae (Figure 2). For a more detailed description of the morphology and internal anatomy please see Purschke [45]. As there is at present only a single species recognized in the genus Parergodrilus, no morphological diagnostic features for species identification are known. However, the possible presence of cryptic species has been suggested. Parergodrilus can be differentiated from Stygocapitella, based on several characters, which among others include the presence of simple chaetae, the lack of bilimbate and whipped chaetae as well as of two praepygidial achaetigerous segments (Figure 2).

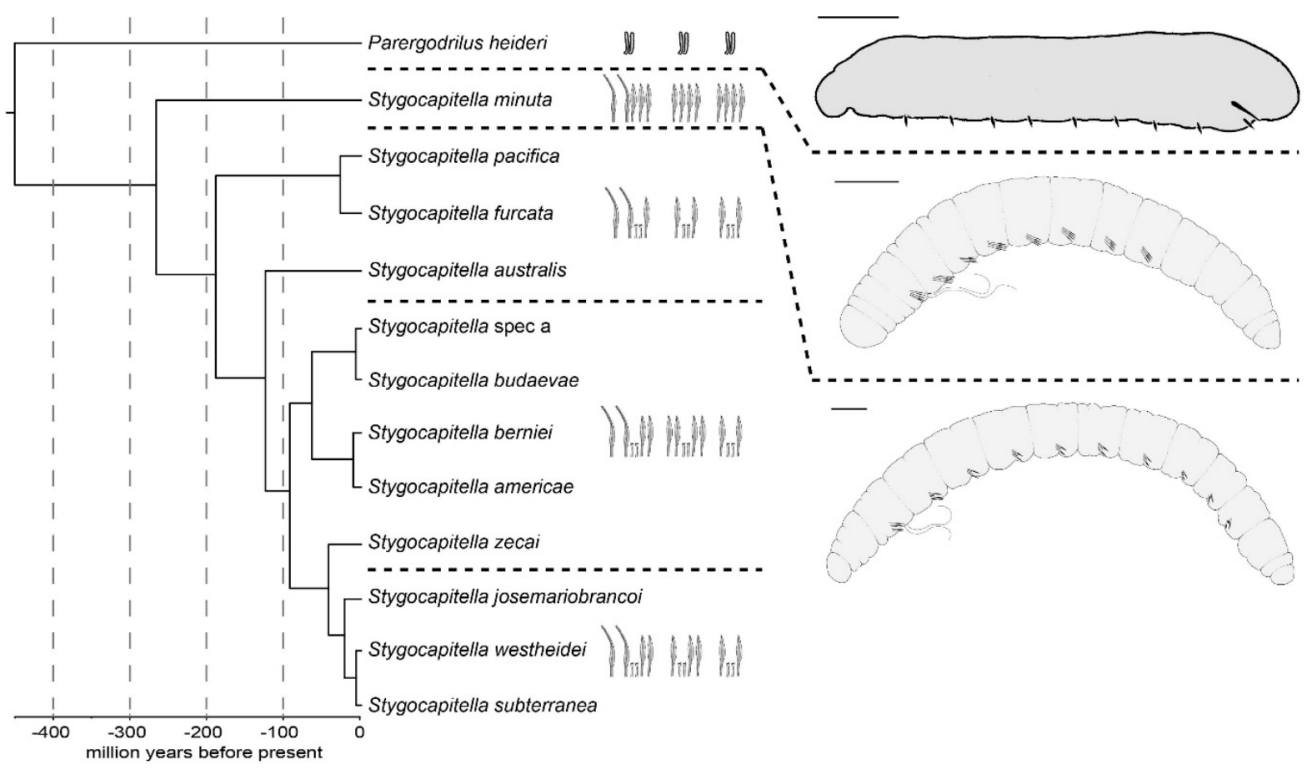

Figure 2. Parergodrilidae based on different sources (Cerca et al. [46]; Cerca et al. [47]; Struck et al. [48]). Besides the species names the different chaetal patterns are shown for the 1st, 2nd and 3rd chaetiger. All following chaetigers have the same pattern as shown for the 3rd. Schematic drawings of the general morphology of Parergodrilus and the two different ones for Stygocapitella are based on Reisinger [33] and Struck et al. [48]. The scale bars equal $125 \mu \mathrm{m}$.

\section{Distribution}

Besides the first records from Austria, $P$. heideri has been found throughout Europe including records from Spain, Italy and Croatia in the South to Sweden in the North (Figure 1D), e.g., [28,30-32,34,36,38-41,49,50]. Recently, also first findings outside Europe have been reported, specifically in Korea and North America (Figure 1A) [37,51]. Hence, the known distribution of $P$. heideri has been strongly expanded in recent years. Even though $P$. heideri is very well studied with respect to morphology, anatomy, and early development by comparison to other meiofaunal species for more details see [45] and is relatively well documented from Europe, many questions concerning the genus' species composition and diversity still remain uncertain or unanswered. The increasing records from atypical habitats indicate that the habitat restrictions are less rigorous than originally considered. Hence, what are the habitat requirements for this species? How sensitive is it truly to desiccation and flooding, different forest types and soil conditions? The center of distribution thus far seems to be Europe and the distribution is seemingly restricted to the Northern hemisphere. Is the lack of Parergodrilus species from the Southern hemisphere and the sparse distribution outside Europe true or does it just reflect a sampling bias with stronger efforts having taken place in Europe? Finally, a thorough taxonomic revision of the species including also molecular data from all records around the world and from different habitats has not been conducted yet. Hence, it is uncertain if cryptic species are present within this species and if such cryptic species could be associated with different habitat 
preferences and/or different regions. For example, do the records outside Europe truly represent the same species? In the same vein, the molecular data will also allow one to assess if the records outside Europe could indicate recent invasions, for example, alongside earthworm introductions or if the species are native species in these areas. Schlaghamerský and Frelich [37] regard the species as native as they regard transport of such small annelids as part of commercial fish bait of anglers (i.e., earthworms) as not very likely. However, they also state, "an initial introduction to North America with soil from Europe cannot be fully excluded".

\subsection{Stygocapitella Knöllner, 1934}

Stygocapitella was first described by Knöllner [25] from a wide sandy beach with medium coarse sediments at the German Baltic coast (Figure 1D). Following records also found Stygocapitella at similar sandy beaches with medium coarse sediments (Figure 3A-C), e.g., [24,52-56]. However, more extensive sampling also at beaches, which are not wide with only medium coarse sediments, revealed that Stygocapitella also occurred at them $[30,43,52,57]$, sometimes in high abundance (personal observations). These beaches could be wide or narrow, with or without stones and pebbles on top of or intermixed with medium-coarse sediment (Figure 3D-G). Usually the specimens can be found around or up to $18 \mathrm{~m}$ above high tide level, but at some beaches of the Thames (i.e., Cutty Sark, UK) and the Nærøyfjord (Bakka, Norway) they are found substantially below high tide level or even at low tide level (personal observations). In the beaches, they occur usually in

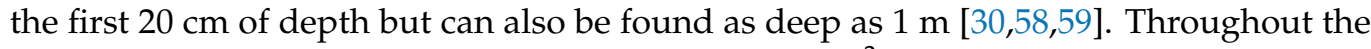
year the abundance is around 10-20 specimens $/ 100 \mathrm{~cm}^{3}$ in most beaches investigated in more detail thus far, but it can occasionally be three to four times higher [30,58,59]. During winter months, the specimens migrate to deeper layers to avoid freezing and the same migration pattern can be observed to avoid desiccation in the uppermost layers [30,58,59]. Generally, Stygocapitella seems to prefer the zone of damp sand in the beach with $3 \%$ water content in relation to the dry weight of the sediment, but they seem to sustain also water content up to $21.5 \%$ [30]. The latter point is further supported by records closer to low tide level, which means that for at least a few hours each day these animals experience complete water saturation. In summary, Stygocapitella is usually found in medium coarse sediments in the damp zone of the upper shore of sandy beaches but occasionally also in sediments with higher water content. These beaches can be differently exposed to tides, small or wide, with or without stones and pebbles.

In contrast to P. heideri, the sex ratio in Stygocapitella is 1:1 and no dimorphism is visible. Reproduction seems to take place throughout the year as all juvenile stages can be observed in all months. The direct development resembles the one of $P$. heideri with eggs being deposited in cocoons and hatching at the four-chaetiger stage. However, the hatchlings are larger with a body length of about $0.75 \mathrm{~mm}$ and do not possess the full complement of chaetae in the first two segments, which develop in the later juvenile stages. Cleavage pattern and duration of development are unknown. In general, $70-90 \%$ of the populations are immature adults [45].

The first described species of Stygocapitella was S. subterranea by Knöllner [25]. Stygocapitella subterranea possesses ten chaetigers plus one achaetigerous segment after the peristomium and two achaetigerious before the pygidium. Three different types of chaetae are present: whipped-like chaetae, bilimbate chaetae and forked chaetae (Figure 2). The chaetal composition at the chaetigers shows a specific pattern in each pair of bundles. At the first chaetiger, each bundle possesses two whipped-like, two forked and two bilimbate chaetae. The second one has one bilimbate, two forked and two bilimbate chaetae. Finally, the third and all following ones have one bilimbate, two forked and one bilimbate chaetae (Figure 2). For a more detailed description of the morphology and internal anatomy please see Purschke [45]. 

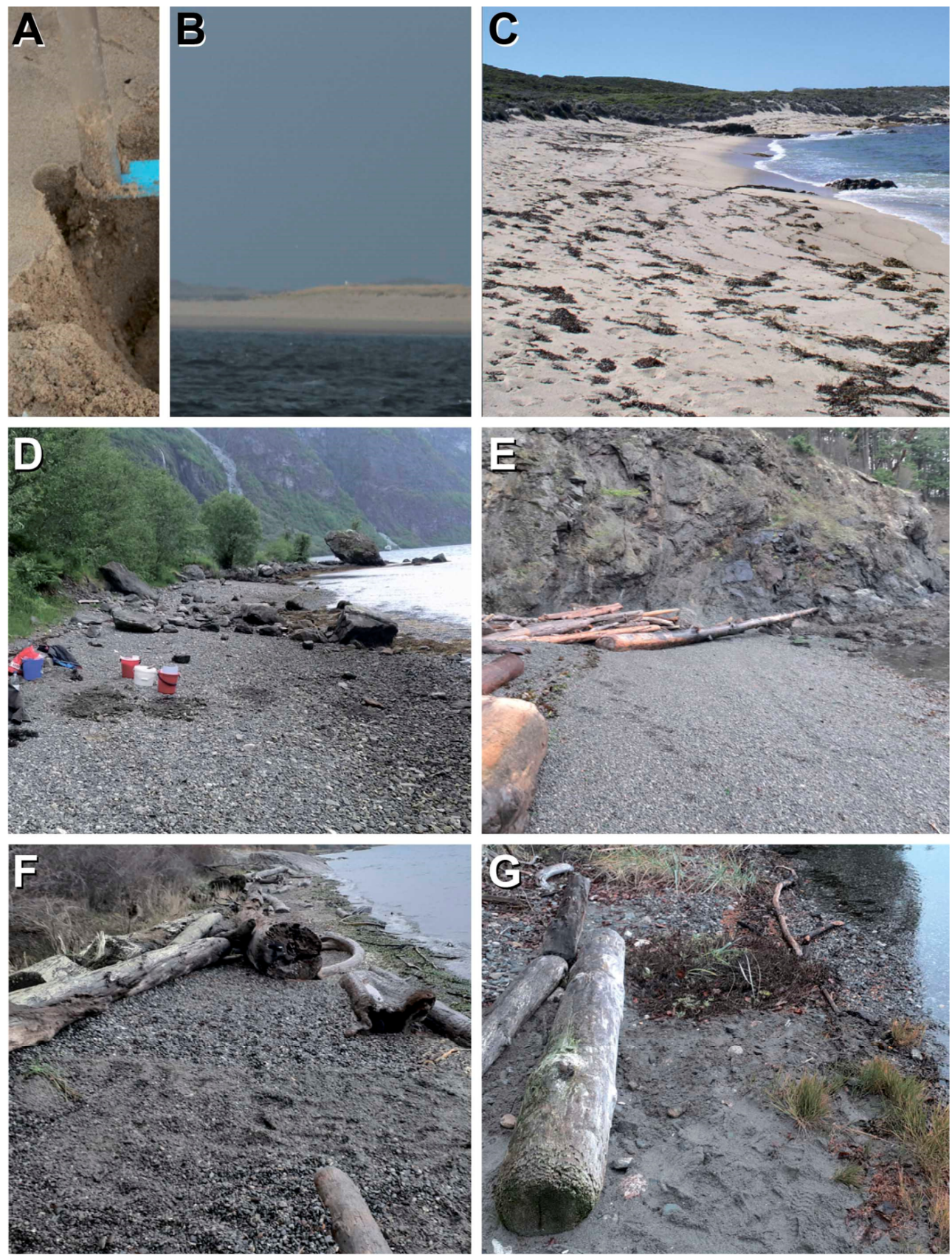

Figure 3. Pictures of the different beaches with known records of Stygocapitella. (A) Medium coarse sediment from Hausstrand, North Sea island Sylt; (B) Ellenbogen, North Sea island Sylt; (C) Sarge Bay, Australia; (D) Bakka, Norway; (E) Reid State Park, San Juan Island; (F) 4th of July beach, San Juan Island; (G) Roche Harbor, San Juan Island.

\subsubsection{Distribution}

After the first description of S. subterranea from the German Baltic Sea [25], this species has also been found at numerous additional beaches in Europe including the North, Baltic, Mediterranean, and Black Sea and the European Atlantic coast (Figure 1D) [24,30,44,50,53,55,58-67]. It has also been found at several beaches outside Europe, in specific North America, Australia, New Zealand and Japan (Figure 1A-C) $[30,52,54,56,57,68]$. Interestingly, all records in both hemispheres are so far restricted to the boreal and temperate zones barely reaching into the subtropical zone (Figure 1A). As there have been several attempts focusing on this species, the distribution gap in the tropics and subtropics seem not to be a sampling effect [45]. All of these records 
were assigned to $S$. subterranea. Therefore, Stygocapitella was often considered a typical example of the Meiofauna paradox as it had a cosmopolitan distribution but seemingly no active or passive long-distance dispersal stage $[57,60,69,70]$. However, a first molecular study with one population each from the US Pacific, US Atlantic and European Atlantic coast indicated that no gene flow between these three populations occurs [57], but no taxonomic action was taken. Additionally, analyses of sperm ultrastructure revealed no differences between the same three populations (Purschke personal communication).

\subsubsection{Taxonomy}

The first record of Stygocapitella, which was not assigned to S. subterranea, was S. minuta Struck et al., 2017, which was found in South Africa (Figure 1A) [48]. The specimens are clearly different from $S$. subterranea as $S$. minuta has only eight chaetigers but four achaetigerous segments in front of the pygdium (Figure 2). Moreover, mature adults are only about $1.5 \mathrm{~mm}$ long and hence much smaller than $S$. subterranea. Forked chaetae are lacking altogether and two additional bilimbate chaetae are present instead. As part of this study specimens from the Australian localities were investigated anew and it could be shown that even though they were overall similar to specimens from the type locality they differed in the chaetal composition. They have one bilimbate chaeta less in the first and second chaetiger (Figure 2). Therefore, these specimens were described as S. australis Struck et al., 2017 (Figures 1A and 2). The morphological results were supported by molecular data showing that there were deep divergences between the three species dating back about 260 and 80 million years, respectively.

This study was followed by a more thorough revision of the genus Stygocapitella by Cerca et al. [46] including several populations from both North American coastlines, Europe and a new record from the Russian Pacific coast. This study found that besides the $S$. minuta-, S. australis- and S. subterranea-morphotypes a fourth morphotype can be observed, which is very similar to the $S$. subterranea-morphotype but differs in the chaetal composition of the second chaetiger by possessing one more bilimbate chaeta (Figure 2). In addition, a few species are smaller than others. However, species delimitation in this study had to mostly rely on molecular data using two mitochondrial and two nuclear markers. In total, twelve different species could be differentiated of which eight were described anew. One species could not be described as no holotype could be assigned. Two of these eight species, S. pacifica and S. budaeva, were completely new to science as they were collected from the Russian Pacific coast, which has not been sampled previously (Figure 1A). Along the North American Pacific coast, three species, S. furcata, S. berniei and S. americae, were described (Figure 1A,B). Hence, including the undescribed species four species previously assigned to S. subterranea occur on San Juan island alone (Figure 1I). At the Northern European coastlines, two additional species, $S$. josemariobrancoi and $S$. zecai, are now recognized besides $S$. subterranea (Figure 1A,D,E-G). The European species S. josemariobrancoi also has a record from the North American Atlantic coast (Figure 1H), where S. westheidei has also been found (Figure 1H). Additional support for these delimitations is gained from the fact that species occur in sympatry at each of these coastlines, which in this case means that they occur within the same beach, often within the same $50 \mathrm{~cm}^{3}$ of sediment (Figure 1A,F-H). Hence, the number of formally described species has increased from one to eleven in recent days and only three of them are due to new records, while the remaining ones have been recorded as $S$. subterranea before. All species are cryptic species except for S. minuta, as it is the only one, which can unaminously be distinguished from all other species based on its morphology [71]. Accordingly, the previously assumed cosmopolitan distribution of $S$. subterranea is no longer given. While several species still show a relatively broad distribution along European, American or Australian coastlines, other species (i.e., S. pacifica, S. budaeva, S. furcata, S. berniei, S. americae and S. minuta) seem to have a very restricted distribution. However, in these latter cases only one population (S. pacifica, $S$. budaeva, and $S$. minuta) or very few populations in close vicinity to each other (S. furcata, S. berniei, and S. americae) have been studied. Finally, all previous records, which have 
been assigned to $S$. subterranea (black triangles in Figure 1), need to be investigated again to assign them to one of these species or even identify a new one. As the morphological characters to differentiate the species from each other are very limited and except for S. minuta restricted to the chaetal pattern at the first two chaetigers and to some degree body size, these new analyses need to include molecular data to be more reliable. As long as this has not been done these records should be treated as Stygocapitella sp.

Besides the geographic distribution, the temporal distribution has also been studied in this complex of cryptic species [47]. It was confirmed that the radiation of Stygocapitella took place about 260 million years ago (Figure 2). More interestingly, the three morphotypes each represented by several species have not changed for at least 18 million (S. subterraneamorphotype) to 140 million years (S. australis-morphotype). [47]. This can also be shown when the morphological disparity is compared to genetic distance. The morphological disparity in this group is about five to eight times lower than, for example, in its sistergroup Orbiniidae or another interstitial group, Nerillidae (Figure 4) [47]. Even at very high genetic distance, it is only half the disparity of these two groups. Hence, these species are clearly affected by morphological stasis and include species with the longest known period of stasis namely S. pacifica, S. furcata and S. australis [46,47].

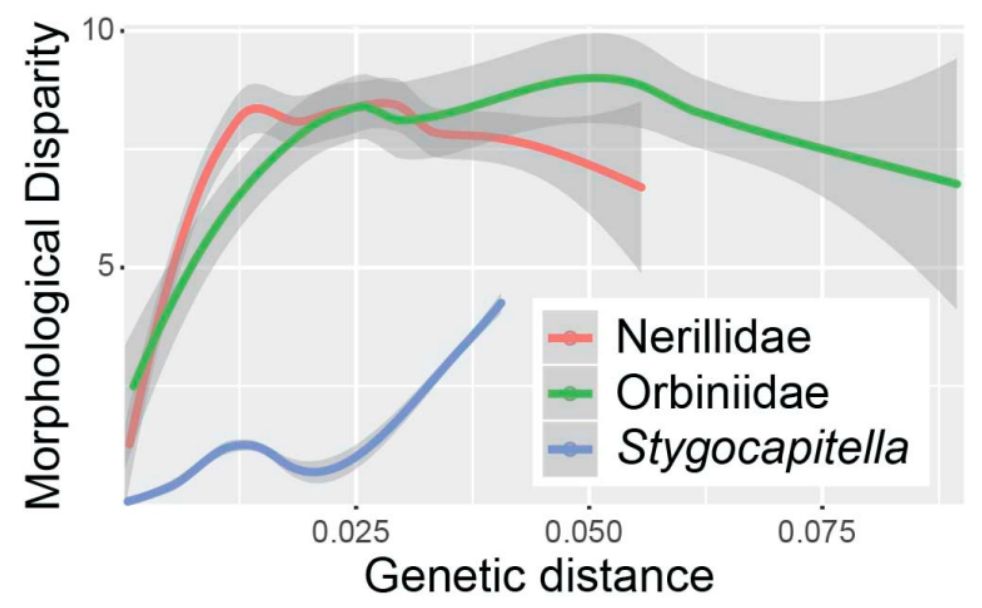

Figure 4. A simplified re-drawing of Figure 5C of Cerca et al. [47]. The plot shows the relationship of morphological disparity measured by pairwise MMD indices in relation to genetic distance measured by pairwise genetic distances of the nuclear $18 \mathrm{~S}$ rRNA marker. The values for Stygocapitella are compared to the sistergroup of Parergodrilidae, Orbiniidae, and another interstitial annelid group, Nerillidae. The grey area indicates the $95 \%$ confidence interval of the fit (line) to the data points (not shown).

\subsubsection{Conclusions}

Besides large-scale differences in the distribution along different oceanic coastlines, no other differences, for example in macroecological factors like annual average temperature, could be detected so far between the species [46,47]. Hence, it is not certain yet, which factors drive distribution, speciation and stasis in these species. However, detailed studies of their different interstitial environments are lacking. The first studies in Europe in this respect $[30,58,59,61,62]$ can only be starting points to investigate these relationships and dependencies and in the light of the new taxonomy the sampling is not sufficient, because what was thought before to be the result of one species is now representing populations from three different species and also includes some sympatric populations. For example, the beaches on the North Sea Island sampled in these studies contain only very rarely S. subterranea, but $S$. josemariobrancoi or species of uncertain status (Figure 1G) $[30,58,59]$.

The dates listed above for divergence of morphotypes or species are too young to be able to explain the recent day distribution of Stygocapitella species by vicariance $[46,48]$. Hence, this distribution must have been established by occasional long-distance dispersal 
events across oceans including at least two times dispersal across the equator leading to the present-day distribution gap [46]. However, how this was accomplished is still uncertain. Moreover, the colonization of S. josemariobrancoi of the North American Atlantic coast must have happened very recently as these specimens share identical haplotypes with European specimens across all molecular markers [46]. This could have possibly been human-mediated distribution, maybe by ballast sand. However, this scenario seems not to occur otherwise in Stygocapitella [72].

In summary, this whole group is very well suited to study the factors causing morphological stasis as well as the drivers of speciation in cryptic species as it allows studying change and stasis at different time scales using morphological, ecological, biogeographic, reproductive biological, developmental, physiological, population dynamic and genomic data. These kinds of data will also help to understand if the different species occupy different microniches allowing to survive in sympatry. However, these kinds of data are also lacking to a very large degree and research in this direction is only just beginning. Moreover, given the recent results there is a high probability that the number of species in this genus will still substantially increase. Finally, due to strong sampling efforts many records are known from Europe and North America, but this is not the case on the other continents. Given the recent findings in South Africa and Russia it is very likely that they also occur in the temperate zones of the Southern hemisphere and along the Western Pacific coastlines is East Asia.

\section{Orbiniidae Hartman, 1942}

Orbiniidae are sedentary annelids which can be distinguished generally from the rest of Annelida by a rounded or pointed prostomium without appendages, one or two achaetous rings of the peristomium (Figure 5A), body separated into thorax and abdomen bearing biramous parapodia (Figure 5B) and branchia disposed dorsally in the abdomen (Figure 5C). This general scheme fits with the medium- to large-sized genera like Scoloplos, Leitoscoloplos, Leodamas, Naineris, Orbinia and Phylo (Figure 5D-F), being at the same time the most frequently reported genera and also the most species-rich genera. The adults of most of the species of these genera measure between 3.5 and $20 \mathrm{~cm}$ in length, though others can be up to $30 \mathrm{~cm}$ long (e.g., some Orbinia). On the other hand, in the small-sized taxa (with adults measuring few $\mathrm{mm}$ ) like in Orbiniella or Pettibonella (Figure 5G), the distinction of the body regions is weak or lacking and some species do not possess branchia (Figure $5 \mathrm{H}$ ). Moreover, Orbiniella branchiata Hartman, 1967 [73] bears three achaetous rings in the peristomium. The presence of crenulations in the capillary chaetae, the autapomorphy of the family, is characteristic to all genera independent of their size and defines the attribution of a species to Orbiniidae [6,74] (see the part on chaetae typology in the discussion on taxonomical characters from this subchapter for details).

The most relevant regional identification keys for orbiniids are those of Day [3] for South Africa, Day [75] for North Carolina (USA), Day [76] and Zhadan [77] for Australia and New Zealand, Kirkegaard [78] for the North Sea, Blake [79] for Southern California (USA), Lopez [80] for the Western Mediterranean and Diaz-Diaz et al. [81] for the Caribbean Sea. A number of keys for the different orbiniid groups are available, such as Gillet [82] and Parapar et al. [83] for Orbiniella, Solis-Weiss and Fauchald [84] for Protoaricinae, Sun and Li [85] for 22 species of Orbinia, Sun et al. [86] for 30 species of Leodamas and Blake [87] for the seven deep-water species of Leitoscoloplos from the Eastern Pacific. 

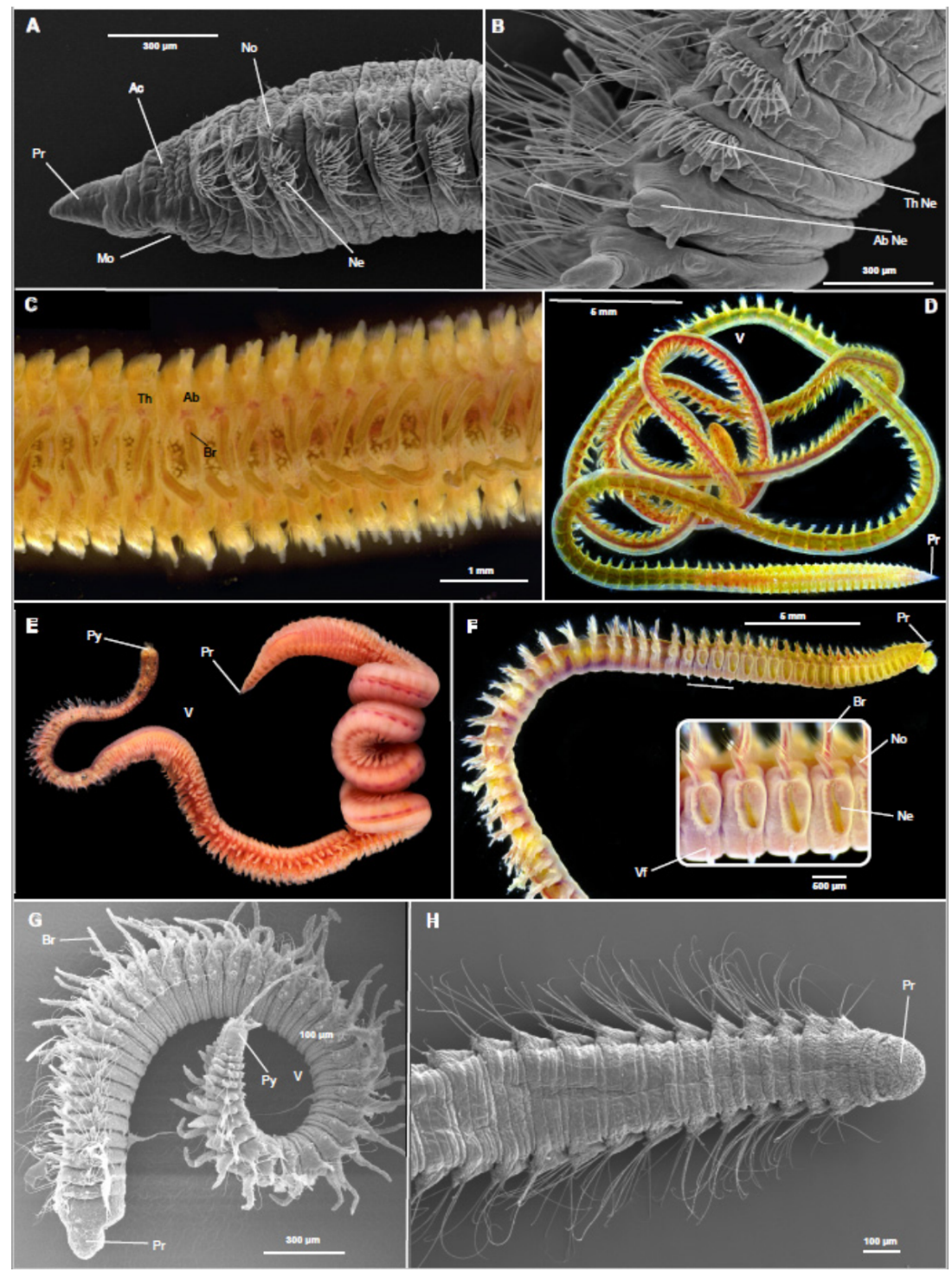

Figure 5. Scanning electron microscopy (SEM) and light microscopy images of different orbiniids. (A). Scoloplos armiger, anterior end. (B). Orbinia cf. armandi, transition thorax-abdomen. (C). Naineris laevigata, detail of the dorsum with branchiae. (D). Leodamas chevalieri, general view of a living specimen. (E). Scoloplos armiger, general view of a living specimen. (F). Phylo kuwaitica, anterior-mid body view of a living specimen and detail of posterior thoracic chaetigers. (G). Pettibonella multiuncinata, general view. (H). Orbiniella sp., dorsum of the anterior end. Ab. Abdomen; Ab Ne. Abdominal Neuropodium; Ac. Achaetous ring; Br. Branchiae; Mo. Mouth; Ne. Neuropodium; No. Notopodium; Pr. Prostomium; Py. Pygidium; V. 1478 Ventrum; Vf. Ventral fringe. Photo E is not scaled.

\subsection{Systematics}

\subsubsection{Morphological Era}

Originally orbiniids carried the name Ariciidae Malmgren, 1867 [88] which has been subsequently changed by Hartman [89] to Orbiniidae, as the type genus of the family, Aricia Savigny 1822 [90], was preoccupied in Lepidoptera. Orbinia Quatrefages 1866 [91] had been designated as the type genus few years earlier [92]. The first important taxonomic work on Orbiniidae systematics belongs to Eisig [93], who reviewed previous works and suggested most of the currently accepted terminology. Later, Hartman [94] performed the revision of orbiniid systematics, in which she redefined all genera, reviewed most of the common species and divided the family into two subfamilies based on the number of the peristomial rings: Orbiniinae (one peristomial ring) and Protoariciinae (two peristomial rings). In the same year, Pettibone [95] reviewed several genera and species based on the material from 
the east coast of North America, describing three new species. The system of Orbiniidae suggested by Hartman [94] was largely accepted until the end of the 20th century and it is still the most comprehensive and detailed work on orbiniids. Nonetheless, there were important contributions to the orbiniid systematics. Day [75] reviewed the generic system for the subfamily Orbiniinae and Solis-Weiss and Fauchald [84] did the same for the subfamily Protoariciinae. Day [76] erected the genus Leitoscoloplos and Mackie [96] revised the genus, transferring some species to the genus Scoloplos. Gillet [82], Parapar et al. [83], and Blake [87] reviewed Orbiniella and Badalamenti and Castelli [97] Schroederella. Blake [98] described Methanoaricia dendrobranchiata, a new species and genus (monotypic up to date) reported from the seeps of the Gulf of Mexico. The discovery of this genus led to the new revision of the whole family. This resulted in the division of Orbiniidae into three subfamilies: Orbiniinae, Microrbiniinae and Methanoariciinae, established for the unusual M. dendrobranchiata. Blake [98] demonstrated that the number of rings in peristomium can vary during the ontogeny in several genera and excluded it from orbiniid taxonomy. Following Blake [79,98], many protoariciins represent the juveniles of other orbiniid genera suggesting synonymization of Pararicia with Protoariciella or Naineris in Blake [79].

\subsubsection{Genetics Era}

The first molecular phylogenetic study of Orbiniidae was conducted by Bleidorn et al. [99]. It included eight orbiniid species among other annelid genera and received strong support for a close relationship between orbiniids and Questidae Hartman, 1966 [100]. Currently, questids are considered part of Orbiniidae [6,101], constituting the genus Questa. Three molecular phylogenetic reconstructions focusing on relationships between orbiniid genera reported several genera as paraphyletic $[19,101,102]$ without support for Hartman's [94] or Blake's [98] classifications. Bleidorn [19] confirmed the placement of Methanoaricia dendrobranchiata within Orbiniidae based on two genes (16S and 18S). Twenty species belonging to 11 different genera were included in the analyses, in which Scoloplos, Leitoscoloplos, Orbinia and Phylo were recovered as paraphyletic. An extension of this phylogenetic reconstruction was made by Bleidorn et al. [101] (Figure 6A) adding to the analyses four more genes (cox1, cox3, nad1 and nad4), six more species and a morphological character matrix. Similar results (i.e., paraphyly of the former genera except for Naineris, which was monophyletic) were obtained even with the expanded dataset, and most of the traditional characters revealed to be useless for phylogeny. The authors suggested that repeated loss of characters and progenesis were the main processes in the evolution of orbiniids. In addition, some of the small-sized species with two peristomial rings (i.e., belonging to Protoariciinae sensu Hartman, 1957) included in the analyses showed significant genetic divergence and, thus, good evidence of being valid species. However, one specimen identified as Protoariciella uncinata Hartmann-Schröder, 1962 [103] was found to be genetically identical with the individuals of Leodamas tribulosus (Ehlers, 1897) [104]. This has partly corroborated the hypothesis by Blake $[79,98]$ that species/genera of Protoariciinae might be misidentified juvenile stages of Orbiniidae. The latest phylogeny focused on Orbiniidae by Zhadan et al. [102] included 53 specimens belonging to 33 species from 12 genera. Three NJ analyses performed independently for COI, 16S and 18S (Figure 6B-D) recovered all genera tested by Bleidorn et al. [101] as paraphyletic; however, the tree topologies were different in the two studies, with Naineris being paraphyletic in Zhadan et al. [102]. 


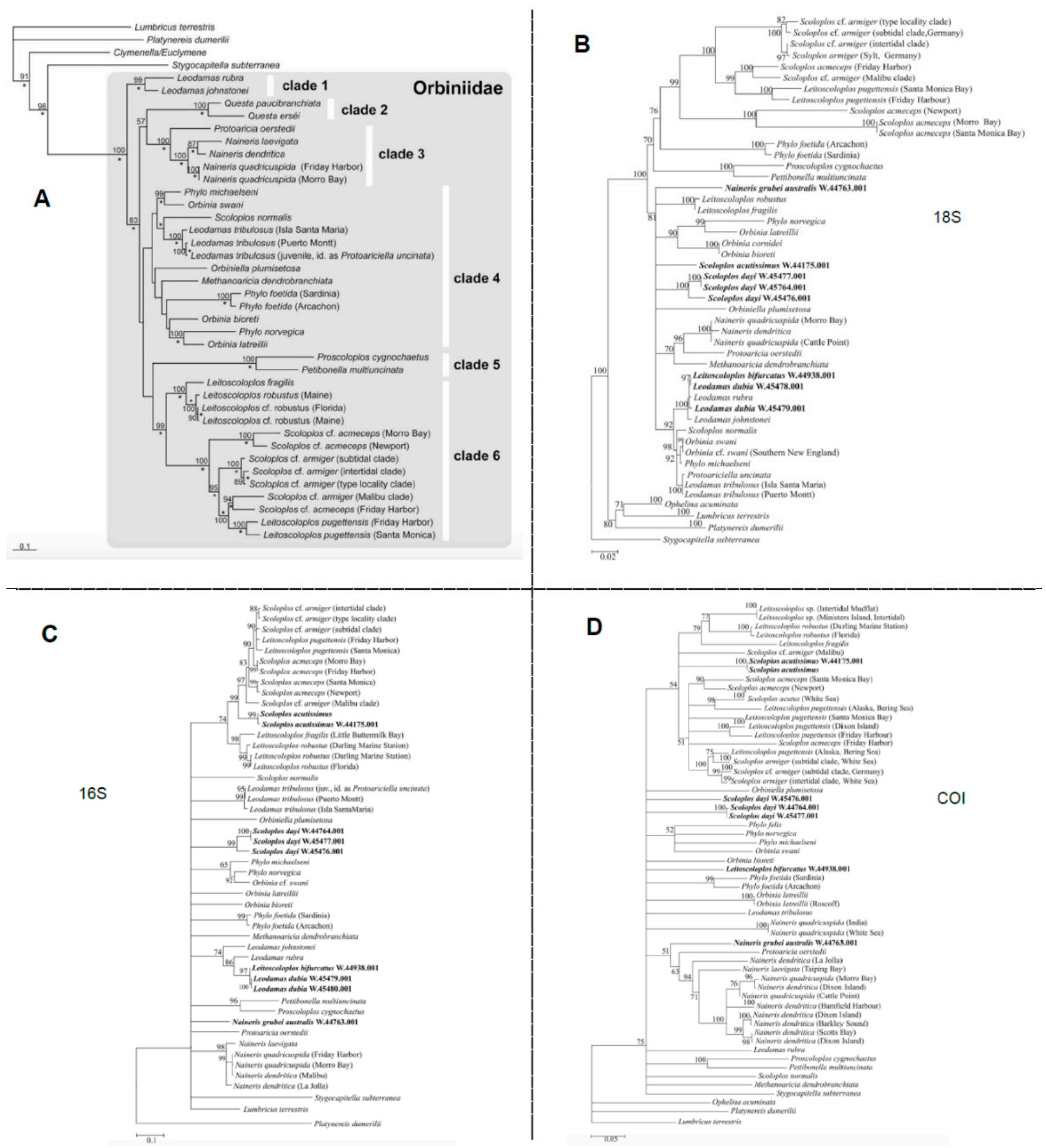

Figure 6. The four phylogenetic inferences performed for Orbiniidae in Bleidorn et al. [101] (A) and Zhadan et al. [102] (B-D). A. Maximum likelihood analyses based on six concatenated gene fragments (18S, 16S, cox1, cox3, nad1 and nad4), resulting in six orbiniid clades. Numbers at the nodes show bootstrap values from 1000 replicates and asterisks $\left(^{*}\right)$ indicate nodes with a posterior probability of $>0.95$ in the Bayesian analysis. (B-D). Three Neighbor Joining analyses based on individual genes (18S, 16S and COI) marked in each tree. The bootstrap values were obtained from 1000 replicates. Most of the clades from $\mathbf{A}$ changed in adding species in (B-D).

\subsubsection{Current State: Traditional Taxonomy vs. Genetics}

Currently, Orbiniidae comprise more than 200 accepted species within 20 valid genera (see the Tables S1 and S2 in Supplementary Materials). Following Bleidorn and Helm [6] these numbers should be taken "with a grain of salt" given the high number of upcoming papers describing new orbiniid fauna [87] and the paraphyly of most of the genera as shown by the molecular analyses. We consider the monotypic genus Scoloplella as 
nonvalid following Bleidorn and Helm [6], as it is undistinguishable from the juveniles of Leitoscoloplos and consequently synonymized. With his monographs of 2017 [74] and 2020 [87], Blake has updated the previously accepted system for Orbiniidae [98], emending the two subfamilies Orbiniinae (Berkeleyia, Califia, Leitoscoloplos, Leodamas, Naineris, Orbinia, Phylo, Protoaricia, Schroederella, Scoloplella, Scoloplos and Uncorbinia) and Microrbiniinae (Microrbinia, Orbiniella, Proscoloplos and Pettibonella), and reviewing the definition of ten genera. Protoariciella was included in Orbiniinae in Blake [74] as problematic and not considered in Blake [87] since only the type species Protoariciella uncinata bore thickened notopodial chaetae in the posteriormost segments, the diagnostic character for the genus. Furthermore, one individual identified as P. uncinata was shown to be genetically identical to Leodamas tribulosus in Bleidorn et al. [101]. The genera Pararicia, Paraorbiniella and Questa were not considered by Blake $[74,87]$ in his redefinition of the orbiniid sufamilies, whilst Scoloplella was included into Orbiniinae.

The morphological characters used in the Blake's generic system generally were the same that Hartman used in her revision from 1957, namely: the shape of the prostomium, the number of thoracic segments, the position of the first pair of branchiae, the shape of the parapodia, the presence/absence of subpodial papillae and their number, and the chaetal characteristics. The characters show high degree of variation among orbiniid species and genera with some species having ambiguous generic placement. This makes the orbiniid system unresolved which has been suggested by Mackie [96] in his revision of Leitoscoloplos even before the molecular analyses emerged. Leitoscoloplos multipapillatus Alcántara and Solís-Weiss, 2014 [105] is an example of a species that combines diagnostic characters of two genera. The species does not have hooks in the thoracic neuropodia characteristic to Leitoscoloplos but bears subpodial and stomach papillae, which, together with the absence of the spear-like spines, suggests its placing within Orbinia. Another example of ambiguous attribution of a species to a genus is Naineris setosa (Verrill, 1900) [106], a large orbiniid with a Naineris-like rounded prostomium bearing only camerated capillaries in the thoracic neuropodia, the diagnostic character of Leitoscoloplos. Furthermore, Orbinia sagitta Leão and Santos, 2016 [107] was erroneously placed into Orbinia lacking subpodal lobes and having Leodamas-like uncini, being similar to Leodamas sinensis Sun, Sui and Li, 2018 [86] (authors' observations).

A phylogeny with sufficient taxon coverage and amount of genetic data is required as a first step for the revision of the orbiniid system. Once the robust phylogeny of the family is constructed, the morphological revision of the well-supported monophyletic clades, in search of synapomorphies, is necessary in order to provide supported system of orbiniids. It is worth saying that none of the known orbiniid species was originally described, both traditionally and currently, incorporating molecular analyses and the only available genetic data in public databases (as GenBank and BOLD) comes from the commented phylogeny papers of Bleidorn, Zhadan and collaborators [19,101,102], other few works as Kruse et al. [108], Meyer et al. [109] or Carr et al. [110] or from unpublished data.

\subsection{Discussion on Taxonomical Characters}

Naineris and Protoaricia are sister groups forming well supported clade on most phylogenetic trees [101,102]. This is the rare case in orbiniid phylogeny when morphological characters are congruent with molecular data. Besides the presence of statocysts mentioned in Bleidorn et al. [101], these two genera also share the dorsal ciliated ridges between branchial bases in abdominal segments and special chaetae in thoracic-subuluncini and cauduncini [93] (p. 216, Figure XIV); [94] (p. 219-221). Progenetic evolution is the best explanation for the similarities between Protoaricia and Naineris [19,101]. Phylogenetic studies with bigger taxon coverage of both genera are needed to confirm this statement. In the following, we discuss some taxonomical characters which are often overlooked or not described well but can be useful for phylogenetic analysis of Orbiniidae.

Dorsal organs are paired ciliated patches usually with a nonciliated mound between them, situated on all abdominal and sometimes on posterior thoracic segments. They are 
serially homologous to nuchal organs [6,94]. In living and sometimes in preserved worms, dorsal organs are marked with pigmentation; however, often the shape of the pigmented spots differs from the shape of ciliated dorsal organs seen with SEM. The dorsal organs are rarely illustrated and described but potentially can serve as genus- or species-specific character. For example, Scoloplos and Leitoscoloplos species have dorsal organs as strait or curved ciliated stripes, whereas Naineris bear five pairs of round ciliated spots [102].

The most promising source of characters useful for phylogenetic analysis of Orbiniidae are shape, number and distribution of chaetae, especially in thoracic neuropodia. Thoracic neurochaetae are organized in several transverse rows in most orbiniids. Hoffmann and Hausen [111] investigated the chaetal arrangement of three species of Orbiniidae belonging to different clades both in morphology-based and sequence-based phylogenies: Scoloplos armiger, Orbinia latreillii and Pettibonella multiuncinata. SEM and 3D reconstructions based on series of histological sections were used to reveal the position of different chaetae, their organizations in rows, the depth of their bases inside the parapodial tissue and the locations of formative sites of the chaetal rows. All three investigated species showed very similar patterns in the thoracic neuropodia: they had anterior main and posterior secondary transverse rows; main rows had a dorsally located formative site, which indicates homology with the transverse rows of other sedentary polychaete taxa. The number of chaetae and the depth of the chaetal bases decreased from frontal to caudal rows. Two additional secondary rows had their own formative site in the dorsoventral middle of the chaetal patch, and they were located along the caudoventral edge of the posteriormost main row and bent frontally. Interestingly, only capillary chaetae were present in the posterior main row and the posterior secondary row in all three investigated species whereas other rows could contain uncini as well as capillaries. The author supposed the described design of the thoracic neuropodia with main and secondary transverse rows represents the ancestral pattern for Orbiniidae [111]. This parapodial pattern is illustrated here on example of juvenile Scoloplos armiger (Figure 7A).

This approach suggested for the study and description of chaetal arrangement seems to be very promising. There were no such detailed investigations of other orbiniid genera, so it is hard to confirm or refuse that the general scheme works for all Orbiniidae; but good quality SEM photos sometimes are enough to reveal the chaetal position in other orbiniid taxa. The species of the genus Leodamas are the most convenient for SEM investigations of the thoracic neuropodia, as their chaetae usually are short and oriented more or less perpendicularly to a body wall. Unfortunately, in most orbiniids SEM images do not allow recording the chaetal arrangement in details, when anterior chaetae are long, oriented in caudal direction and cover the bases of posterior chaetae; also, chaetal rows can be not obvious, like in many Scoloplos and Leitoscoloplos species. In this situation special efforts are necessary to illustrate the chaetal position in neuropodia; it can be parapodia, mounted with different angles, parapodia with broken chaetae to show only their bases, serial histological sections with 3D reconstructions or confocal laser scanning microscopy (cLSM), which allows one to see chaetae themselves by autofluorescence as well as formative and degenerative zones with specific markers.

Here we present the attempt to analyze chaetal arrangement in thoracic neuropodia of different orbiniid taxa and compare them with Hoffmann and Hausen's [111] scheme using published SEM photos. Leodamas acutissimus (Hartmann-Schröder, 1991) [112] has thoracic neuropodia which are in good agreement with the orbiniid general pattern, including the presence of capillaries only in posterior main row and posterior secondary row. It has three of four main rows consisting of uncini, then a short main row consisting of capillaries which is located only in upper half of the neuropodia; and two secondary rows, anterior consisting of uncini and posterior row of capillaries, both located only in lower part of the neuropodia. The length of uncini increases from anterior to posterior rows. Unlike other orbiniids discussed here the last row is situated behind the papilla of postchaetal lamellae (Figure 7B). A similar pattern is found in thoracic neuropodia of Orbinia camposiensis Leão and Santos, 2016 [107]. It differs by a longer first secondary row which is bent frontally 
under the main rows and a reduced posterior secondary row with two capillaries only (Figure 7C). Leodamas verax Kinberg, 1866 [113] (the type species of the genus Leodamas) was redescribed with designation of the holotype by Blake [74]. Its thoracic neuropodia bear three main rows of uncini and one short secondary row, consisting of longer uncini; it is curved down frontally under the main rows; capillary chaetae are totally absent. Unlike general pattern of orbiniids sensu Hoffmann and Hausen [111], the length of the chaetae in the main rows decrease from anterior to posterior (Figure 7D). The same neuropodial arrangement was found in Leodamas cirratus (Ehlers, 1897) [104] (Figure 7E). Unlike L. acutissimus and L. verax, Leodamas dubia (Tebble, 1955) [114] from Australia had four main rows containing uncini and a tuft of two capillaries in the uppermost position of the third row. Uncini of the posterior row were the longest, which correspond with Hoffmann and Hausen's [111] description but no sign of secondary rows was seen; also, capillaries were located in the third, and not in the posterior row (Figure 7F). Califia bilamellata Blake, 2017 [74] has three main rows of uncini and no secondary rows (Figure 3G). The given examples show that the scheme suggested by Hoffmann and Hausen [111] has many modifications among Orbiniidae. When the phylogenetic tree of Orbiniidae is obtained, tracing of various states of this character will help one to understand the evolution of chaetal arrangement in this group. Especially interesting to investigate are the spear-shape chaetae in the genus Phylo. According to Hartman [94] (p. 222), the oldest chaetae in the row is the uppermost one. It means the formative site should be ventral, so these specialized chaetae supposedly grow in the opposite direction to uncini of other studied genera.

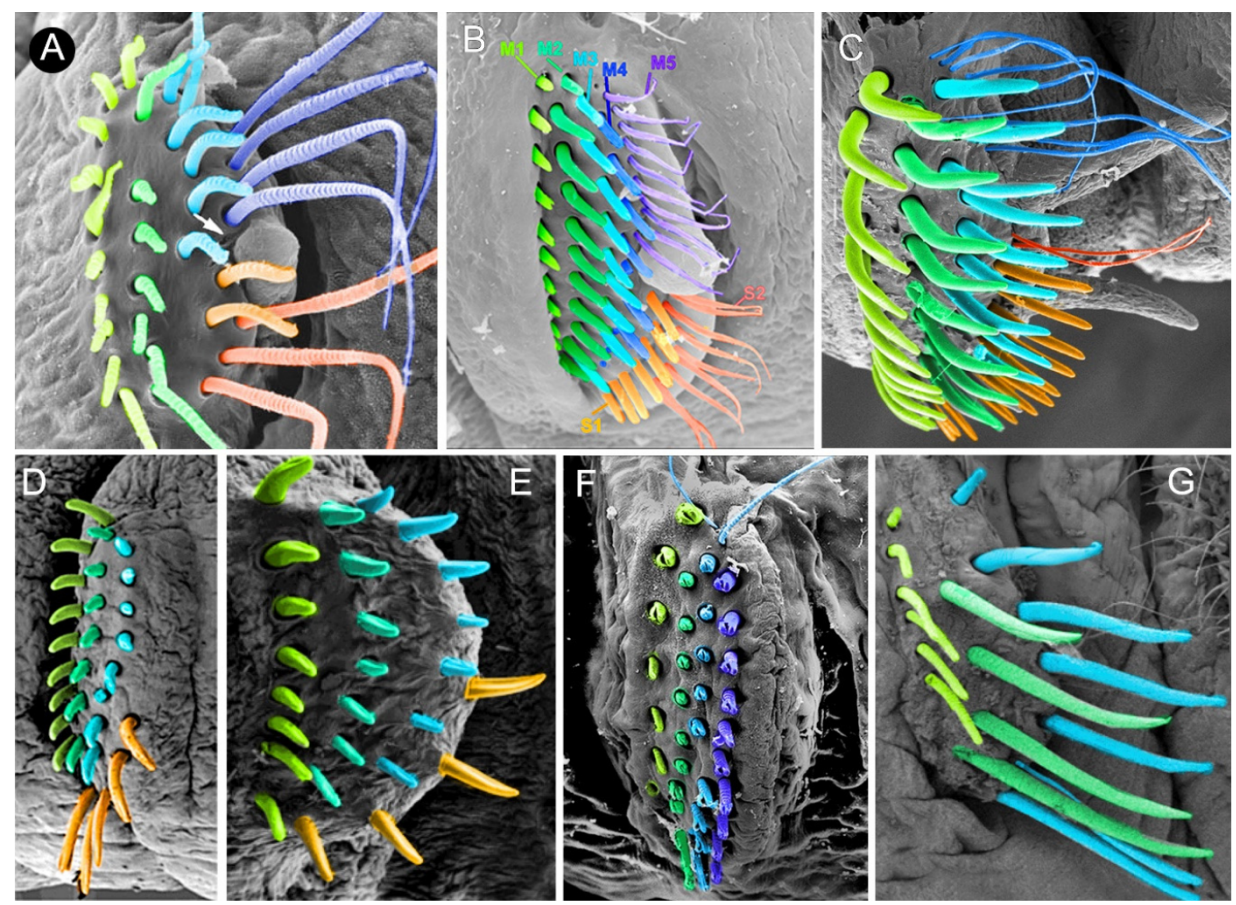

Figure 7. Thoracic neuropodia of Orbiniidae with colored rows of chaetae, SEM. (A). Scoloplos armiger, juvenile, Ch 1; (B). Scoloplos acutissimus, Ch 11; (C). Orbinia camposiensis, Ch 18; (D). Leodamas verax; (E). Leodamas cirratus; (F). Leodamas dubia, Ch 15; (G). Califia bilamellata, Ch 3. Rows designations are given according to Hoffmann and Hausen [111]: green, blue and purple colors indicate main rows (M1-M5), orange and red-secondary rows (S1, S2; white arrow points formative site). The anterior end is on the left in all photos. A: after Hoffmann and Hausen [111]; (B,F): after Zhadan et al. [102]; (C): after Leão and Santos [107]; (D-G): after Blake [74]. Photos are not in scale.

In addition to the arrangement of chaetae in parapodia, the ratio of different types of chaetae is important for orbiniid taxonomy. For example, Leitoscoloplos bear capillaries only, different Scoloplos species-both uncini and capillaries in different proportions, and 
some Leodamas species-uncini only. Cryptic species of Scoloplos armiger complex can be distinguished by the number of uncini in thoracic neuropodia (unpublished data).

The most common chaetal type for Orbiniidae is crenulated capillaries. They can be present in notopodia and neuropodia and in thorax and abdomen. The crenulations are formed by transverse rows of barbs (Figure 8A,B,I). On capillaries, these structures are also called camerations, which may be single, double or in a form of interlocking transverse ribs [74]. Similar crenulations are also present in other types of chaetae (Figure $8 \mathrm{D}, \mathrm{G}-\mathrm{I}, \mathrm{L}, \mathrm{N}-\mathrm{Q}, \mathrm{S}-\mathrm{V})$. Some more types of specialized chaetae are known in orbiniids. Acicular spines are present in neuropodia and sometimes in notopodia in Orbiniella (Figure $8 \mathrm{C}$ ). Forked chaetae occur in abdominal notopodia in many orbiniid species [74] and they have two unequal tynes with blunt or tapered tips. Those with a blunt tip have a distinct hole in the tip. Flattened filaments arise from inner part of the tynes (Figure 8D,E). Swan-shape chaetae are present in both noto-and neuropodia in posterior body of Proscoloplos and Pettibonella (Figure 8F) and most probably evolved convergently to uncini [111]. Flail chaetae are similar with capillaries but have abruptly tapering tips (Figure 8G); they occur in abdominal neuropodia (sometimes in notopodia) in many orbiniid genera. Subuluncini are intermediate between uncini and capillaries having thick bases and pointed tips (Figure $8 \mathrm{H}$ ). Abdominal parapodia bear thick protruding aciculae that can be smooth or serrated, straight or strongly hooked (Figure 8I-K). Other types of chaetae not illustrated here are brush-tipped uncini of Califia, bifid and trifid crochets of Questa, spear-shape chaetae of Phylo, and hirsute spines of Orbiniella spinosa Blake, 2017 [74] (pp. 112-113, Figure $54 \mathrm{~F}, \mathrm{G})$.

Uncini (also called hooks, crochets, spines, blunt-tipped chaetae) differ by curvature, serration, comparative thickness and length, development of a hood, shape of tips and presence of grooves. They vary from notably (Figure $8 \mathrm{~L}-\mathrm{N}$ ) to slightly bent (Figure $8 \mathrm{O}-\mathrm{R}$ ) or are straight (Figure $8 \mathrm{~S}-\mathrm{V}$ ). They can be coarsely (Figure $8 \mathrm{~L}$ ), moderately (Figure $8 \mathrm{O}-\mathrm{Q}, \mathrm{U}$ ) or slightly (Figure $8 \mathrm{~N}, \mathrm{~S}, \mathrm{~T}$ ) serrated or smooth (Figure $8 \mathrm{R}$ ). The number of denticles varies from three (Figure $8 \mathrm{~L}$ ) to 10-15 (Figure 8O,P). Uncini can be long and have the same thickness as capillaries (Figure 8O,P) or be short and much thicker (Figure $8 \mathrm{~V}$ ). They can have a clearly visible hood (Figure $8 \mathrm{~N}, \mathrm{Q}, \mathrm{T}$ ), a thin, poorly visible hood (Figure $8 \mathrm{~L}, \mathrm{O}, \mathrm{S}$ ) or lack a hood (Figure $8 \mathrm{R}$ ). Sometimes the hood is as thick as the chaeta itself, so the impression of bidentate tips arises (Figure $8 \mathrm{P}, \mathrm{V}$ ). The tips of uncini are always more or less rounded, but the exact shape varies from conical to obtuse (Figure $8 \mathrm{O}, \mathrm{Q}, \mathrm{R}-\mathrm{U}$ ). In some species, uncini bear a longitudinal groove on the distal end, which can be short and shallow (Figure $8 \mathrm{~S}, \mathrm{Q}$ ) or long and deep, so the tip of the chaetae is deeply notched (Figure $8 \mathrm{~N}$ ). Often uncini have different shape and size in anterior and posterior thoracic segments (Figure $8 \mathrm{~L}, \mathrm{M}$ ) or even in one parapodia in different rows (Figure $8 \mathrm{~V}$ ).

The functional role of different types of chaetae in Orbiniidae is not clear. Generally, capillaries are believed to be important in locomotion, stabilization during peristalsis and sensing the environment; they also help to irrigate borrows and tubes [116]. Most likely, capillaries in Orbiniidae perform all these functions. For large orbiniids with dorsally elevated abdominal parapodia, it can be that notopodia with notochaetae form a channel covering branchiae, which produce a water current inside it with cilia. Hooks (including spines and uncini) play a role in anchoring polychaetes [116]. As orbiniids are not tube dwellers, they possibly use uncini for preventing backward slipping during burrowing in sediment, but this statement needs to be proven in experiments and live observations. The function of forked, flail and other types of orbiniid chaetae is unknown.

A promising approach which can be used for species delimitation when the morphological differences between lineages are subtle is morphometrics. The characters more suitable for morphometry in orbiniids are from the cephalic regions (i.e., prostomium, achateous segments), parapodia (i.e., neuropodial and notopodial lobes, both thoracic and abdominal, and subpodal papillae), branchiae and the ventral side. Morphometrics has proven useful in annelid groups such as Hesionidae [117,118], Phyllodocidae [119], Syllidae [120] or Nereididae [121]. The only morphometric study performed in Orbiniidae was 
implemented by Hernandez-Alcantara and Solis-Weiss [105] to distinguish Leitoscoloplos multipapillatus among its coexistent Leitoscoloplos panamensis (Monro, 1933) [122] and a third taxon, Leitoscoloplos sp., in the Gulf of California.
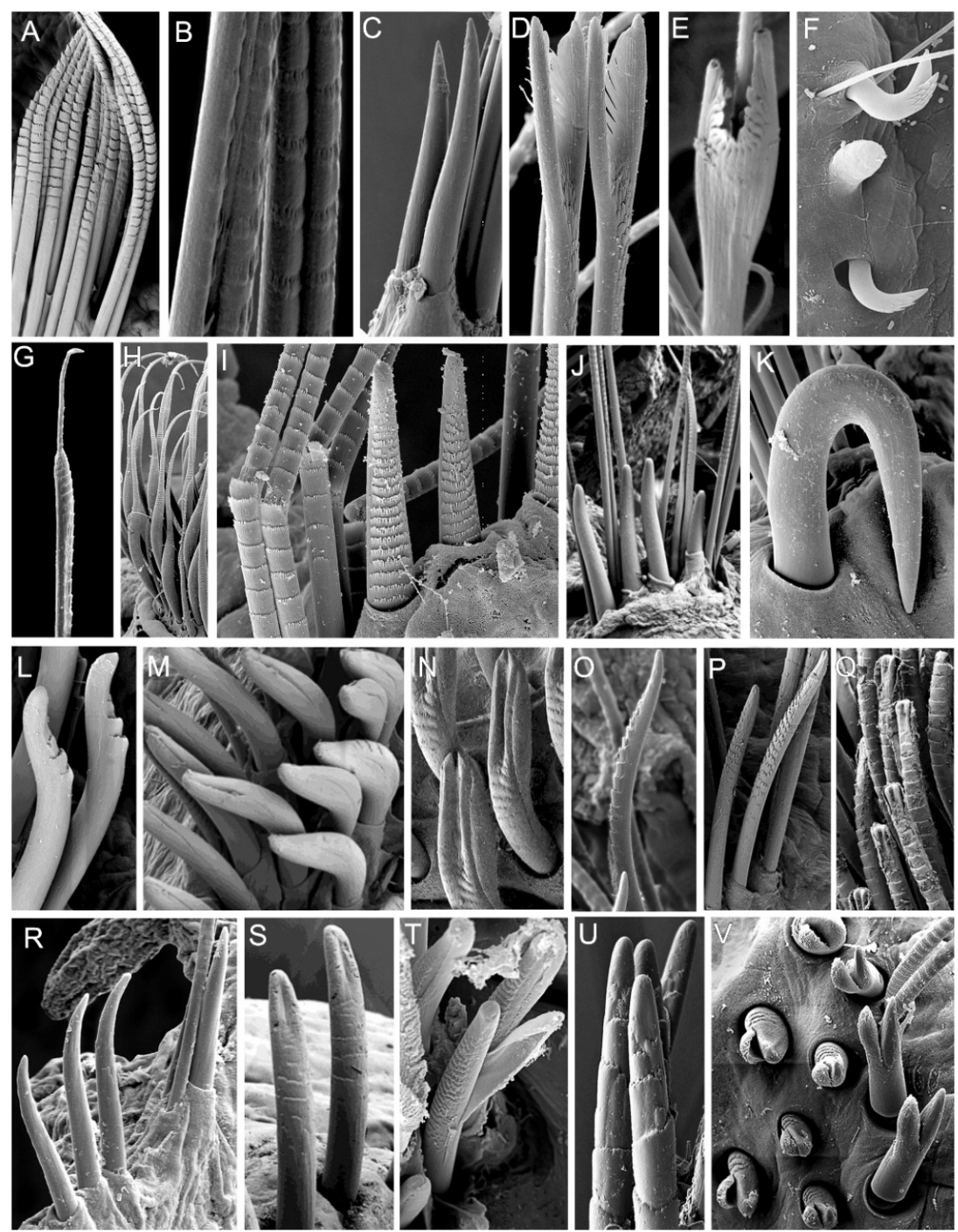

Figure 8. Chaetae of Orbiniidae. (A). Orbinia orensanzi, thoracic notopodial capillaries; (B,C). Orbiniella andeepia, anterior capillary notochaetae and notopodial spines respectively; (D). Leodamas dubia, forked chaetae of abdominal notopodia; (E). Scoloplos bathytatus, forked chaeta of abdominal notopodia; (F). Proscoloplos cygnochaetus, posterior parapodium; (G). Orbinia camposiensis, flail chaetae from abdominal neuropodium; (H-J). Naineris grubei australis, subuluncini of thoracic neuropodia and abdominal neuropodial capillaries and spines, respectively; (K). Leodamas dubia, abdominal neuropodial acicula, protruding and strongly hooked; (L-V): thoracic neuropodial uncini. (L,M). Orbinia orensanzi, from middle and posterior neuropodia respectively; (N). Leodamas tribulosus; (O). Scoloplos bathytatus; (P). Scoloplos suroestense; (Q). Naineris grubei; (R). Scoloplos maranhensis; (S). Leodamas verax; (T). Scoloplos dayi; (U). Leodamas hyphalos; (V). Leodamas dubia. (A-C,E,J,L-Q,S,U): after Blake [74]; (D,H,I,K,T,V): after Zhadan et al. [102], (F): after Meyer et al. [109]; (G): after Leão and Santos [107]; (R): after Oliveira et al. [115]. Photos are not in scale.

\subsection{Diversity \\ 3.3.1. Species Numbers}

Since the first described orbiniid, Scoloplos armiger (Müller 1776) [123], the number of reported species was increasing slowly until Hartman's revision in 1957 [94] accepting 74 valid species (Figure 9). Several new orbiniids were described in different studies following Hartman's system $[73,124-127]$ and, as a result, the species number reached around 
120 [1]. During the following years, several local faunistic studies of Orbiniidae were performed [76,82,84,96,97,112,128-142]. Rouse [143] listed around 150 species of Orbiniidae; twice as much as Hartman [94] defined in her monograph less than 50 years earlier. The 21st century brought several important contributions to the knowledge about orbiniid diversity $[83,85,86,98,107,144-151]$. The two recent works by Blake $[74,87]$ described 37 new orbiniids from which 23 were from the deep-sea (deeper than $500 \mathrm{~m}$ ), and among them, 18 were from more than $1500 \mathrm{~m}$ depth. These studies aid a better understanding of the deep-sea orbiniid diversity, increasing the number of reported deep-sea species from 28 to 51. Bleidorn and Helm [6] listed 204 valid species belonging to 20 genera and Blake [87] reported 240 species of orbiniids; however, here we report 222 species including all described subspecies (commented below).

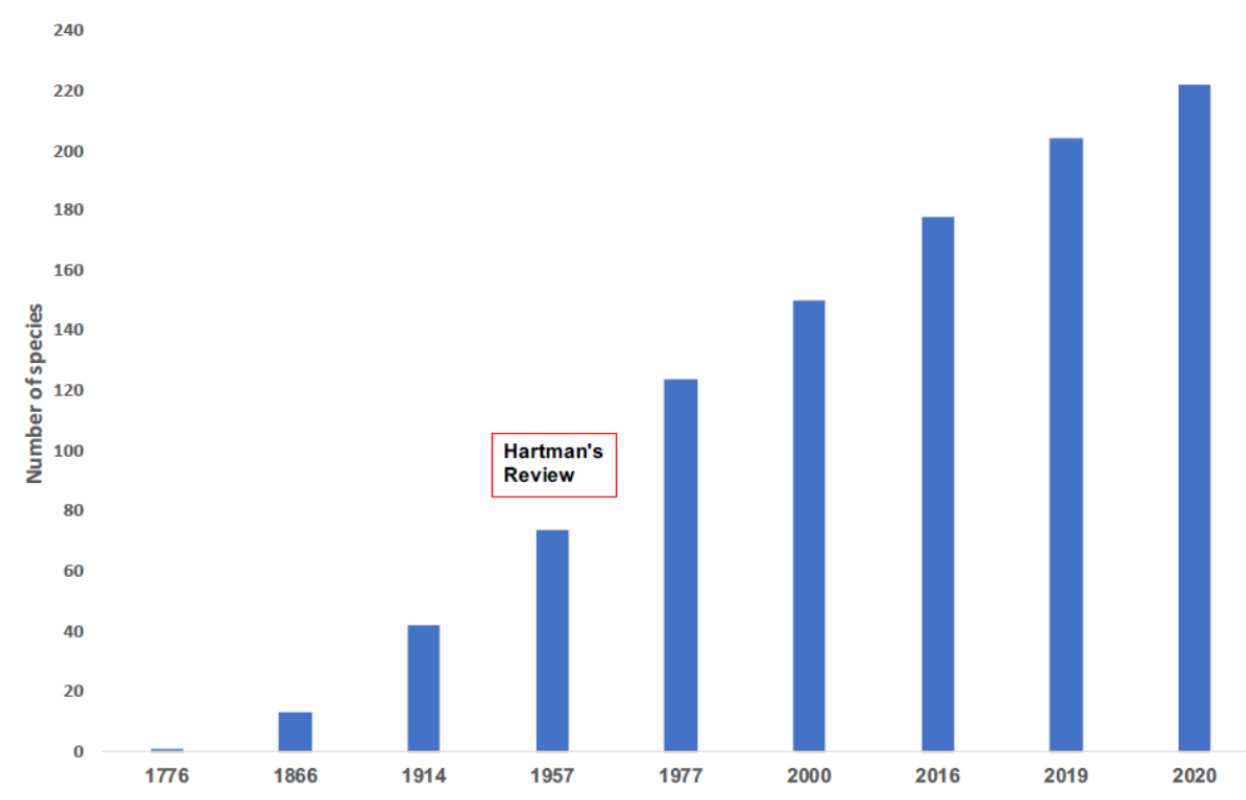

Figure 9. Bar diagram showing the evolution of the number of known orbiniid species from the first described species, Scoloplos armiger, in Müller [123] to this study. Note the exponential growth in species discoveries after Eisig [93] and, specially, during the subsequent decades to the Hartman's review [94].

\subsubsection{Species Distribution}

Orbiniidae occur world-wide in all marine depths, being most common, sometimes forming dense aggregations, in intertidal and shallow waters down to $500 \mathrm{~m}$. Their diversity, depending on the region, can vary from having a great number of species (e.g., 14 in Southern California) to few (e.g., three in the White Sea). The most diverse areas in terms of number of reported species are Asia (with 45 species and 10 genera), the Pacific North America (with 42 species and 10 genera), the Atlantic North America (with 33 species and 16 genera) and the Atlantic South America (with 33 species and 9 genera) (Figure 10). The variation on the orbiniid diversity in certain areas possibly reflects the systematic efforts done by different researchers (e.g., Hartman, Fauchald or Solis-Weiss in the North East Pacific, the Gulf of Mexico and the Caribbean Sea; Lana, Almeida or Pagliosa in the South West Atlantic; Day in South Africa; Hartmann-Schröder or Hutchings in Australia). The poorly studied areas (e.g., East Coast of USA and Canada, South Eastern Pacific, Western Africa or Indo-West Pacific) may have a great number of still undiscovered species.

The deep-sea orbiniids (below $500 \mathrm{~m}$ ) are rarely encountered and poorly known [87]. The 51 species of Orbiniidae from the deep-sea habitats are from Leitoscoloplos (12), Orbiniella (11), Leodamas (6), Scoloplos (6), Berkeleyia (4), Califia (4), Phylo (4), Naineris (3) and Microrbinia (1). The genera Orbiniella, Berkeleyia, Califia and Microrbinia are composed mainly by deepwater species. From all these species, only Microrbinia linea Hartman, 1965 was reported as 
dominant at $2000 \mathrm{~m}$ depth off North Carolina (Western North Atlantic) during a monitoring program conducted from 1983 to 1987 [152]. Relatively dense populations of two other species were reported by Blake [87]: Leitoscoloplos gordaensis Blake, 2020 (with 31 specimens in a single HOV Alvin core from the Gorda Ridge, Escanaba Trough, 3271m) and Naineris uncinata Hartman, 1957 (with 30 specimens from a multicore deployment at a gas hydrate site on the Cascadia Subduction zone off Oregon, $786 \mathrm{~m}$ ). The deepest recorded orbiniid is Berkeleyia hadala Blake, 2017, which was found in $6143 \mathrm{~m}$ in the abyssal plain from the Peru-Chile Trench.

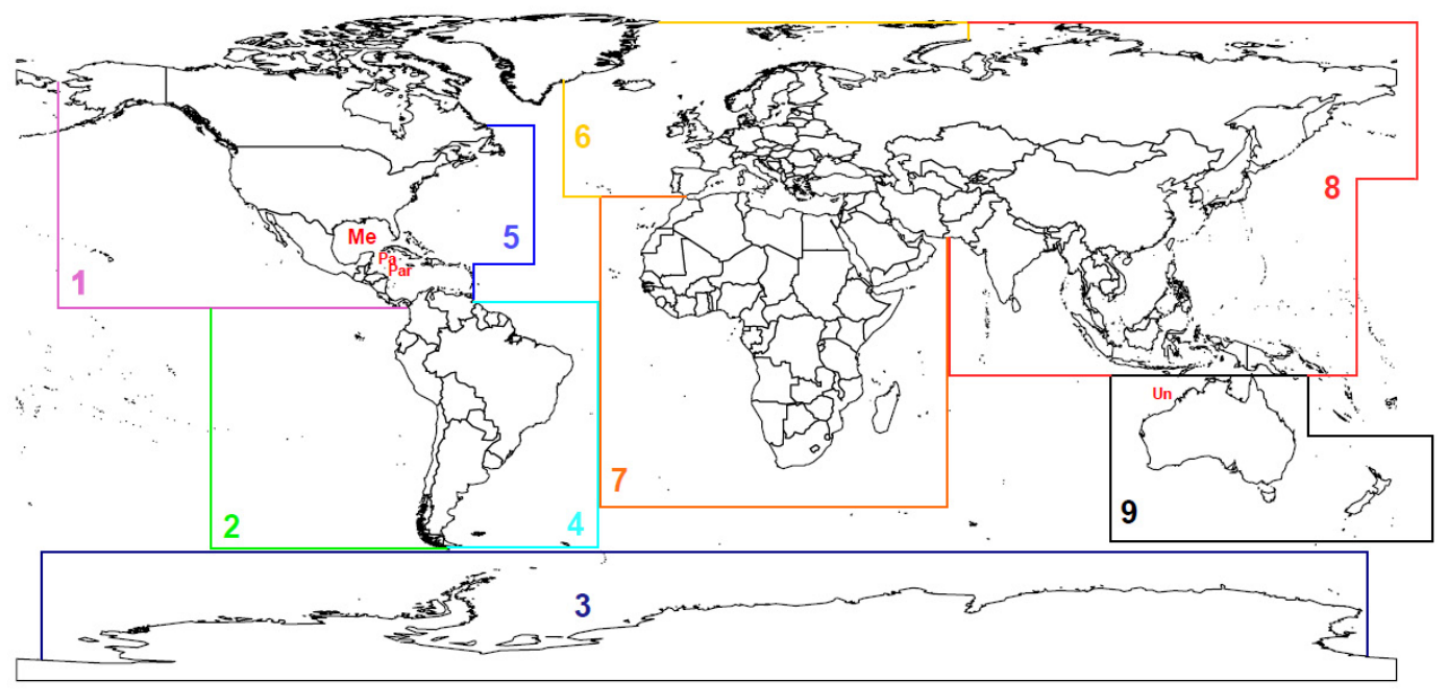

Figure 10. The nine biogeographic areas used for the review of the Orbiniidae diversity distribution with, first, the number of species records and, second, the genera reported for each area. (1). Pacific North America (42, 10); (2). Pacific South America $(23,10) ;(3)$. Antarctica $(18,7) ;(4)$. Atlantic South America $(33,9) ;(5)$. Atlantic North America $(33,16) ;(6)$. Europe $(31,11) ;(7)$. Africa $(32,13) ;(8)$. Asia $(45,10) ;(9)$. Australia and New Zealand $(29,7)$. The monotypic genera based on the original report are represented: Pa. Paraorbiniella paucibranchiata; Par. Pararicia belizensis; Un. Uncorbinia brevibranchiata. The restricted distribution of the monotypic genus Methanoaricia is also marked: Me. M. dendrobranchiata. Map was generated using the R packages ggplot2 and sf.

The most widely distributed species are Scoloplos armiger and Naineris laevigata. The first revealed to be a complex of cryptic species (see details below), while the status of the second has not been confirmed yet with molecular data. Naineris laevigata was first described from Nice (France) and later reported from different localities around the Mediterranean Sea as well as in other distant locations in North and South America, South Africa and Asia. Other widely distributed orbiniids are Naineris quadricuspida (Fabricius, 1780) [153], Phylo felix Kinberg, 1866 [113], Phylo norvegicus (M. Sars in G. O. Sars, 1872) [154], and Protoaricia oerstedii (Claparède, 1864) [155], the status of the last three has not been tested yet. For the first, a significant genetic differentiation was reported in Zhadan et al. [102] between three genetically identical specimens from three locations (i.e., Friday Harbor, Morro Bay and Cattle Point) in the North East Pacific and two genetically identical specimens from two distant places (i.e., India and White Sea) (Figure 6D), but more data is required for confirming a nonworldwide distribution pattern. An interesting case of a confirmed nearly cosmopolitan distribution was reported in Proscoloplos cygnochaetus Day, 1954 [156]. Analysis of morphology and genetics of three different species of Proscoloplos from Australia, South Africa and France revealed a single species with a wide geographical range [109]. The authors suggested a possible human transport by vessels and, thus, an invasive nature of the species. A similar case is that of Naineris setosa, an alien orbiniid in the Mediterranean Sea. The species showed an American subtropical-tropical distribution (see Table S1 in Supplementary Materials for details) and was reported, first, from an aquiculture facility in the Adriatic Sea (Italy) by Blake and Giangrande [157] and, later, in Tunisia by 
Khedhri et al. [158]. However, the status of the "alien" populations vs. the "native" ones in N. setosa has yet to be confirmed. Scoloplos capensis (Day, 1961) has been recorded as an alien species in the Bay of Bengal (India) with a South-African origin [159,160]. Naineris quadraticeps Day, 1965 [161] was described from the Red Sea and afterwards noticed in the Aegean Sea [162] based on two incomplete specimens in poor conditions. Harmelin [162] considered the specimens as juveniles of $N$. quadraticeps, with some minor differences attributed to their juvenile condition. As the record is based on two juveniles, it is considered doubtful [160]. Leitoscoloplos kerguelensis (McIntosh, 1885) [163] has been recorded globally but considered as an Antarctic and sub-Antarctic exclusive species by Blake [74] and as an alien species in the Thyrrenian Sea [164] based on an incomplete specimen. Mackie [96] compared this specimen with the type material and concluded that they have some differences, considering the record in the Mediterranean as doubtful.

\subsubsection{Cryptic Diversity and Subspecies}

Cryptic species have been reported for Scoloplos armiger, Phylo foetida (Claparède, 1868) [165], Scoloplos acmeceps Chamberlin, 1919 [166], Leitoscoloplos pugettensis (Pettibone, 1957) [95] and Naineris dendritica (Kinberg, 1866) [101,110,167,168]. Another potential sibling species issue is known for Leitoscoloplos acutus (Verrill, 1873) [169] and Leitoscoloplos mammosus Mackie, 1987, two similar species with overlapping distributions (see below for details).

Scoloplos armiger was originally described from Kristiansand (Norway) and later reported in several ecological studies [79,170-175] being a dominant macrofaunal species and showing a cosmopolitan distribution with records at the Pacific North American coast, in Europe, including the Arctic and the White Seas, and Japan. It has been reported to be a complex of cryptic species based on, first, RAPD DNA markers [108] and, later, mitochondrial markers [168,174], with at least two clades in the Pacific region (designated as "Malibu clade" and "San Diego Clade") and four clades in the North Sea (named "Type locality clade", "Subtidal clade", "Intertidal clade" and "Intertidal clade 2"). Recent morphological studies performed on the Scoloplos populations from Southern California revealed three morphotypes of $S$. armiger-like species and two of $S$. acmeceps-like species (Haggin, pers. comm.). The study of the genetic clustering among these morphotypes and their relationships with the reported clades by Bleidorn et al. [168] is in process with the aim to describe the species recovered in phylogenetic analyses. Similarly, the species descriptions referred to the North Sea's clades is in preparation [6]. In addition, the populations of S. armiger from the White Sea have been shown to constitute two clades (Zhadan, unpubl.). The eight documented clades of $S$. armiger are accompanied by subtle diagnostic morphological characters and, in the case of the European populations, along with separation by depth. In the North Sea, two clades are known from the intertidal and the other two from the subtidal and, in the White Sea, one is from the intertidal and the other from the subtidal and close to the "Type locality clade". Moreover, two distinct reproductive modes occur in the North Sea's populations [176]. Intertidal females produce egg cocoons, but no pelagic larvae, while subtidal females produce pelagic larvae, but no egg cocoons. Furthermore, the intertidal males have spermatozoa with heads twice as long as those in subtidal males and also a significantly shorter flagellum. The subtidal clades showed an additional autumn spawning [177]. The authors suggested that the difference in the sperm morphology could cause the reproductive isolation at the fertilization stage.

Leitoscoloplos pugettensis is a common macrofaunal component in the West Coast of North America, from Alaska to Costa Rica, being the most abundant orbiniid in intertidal and subtidal bottoms in California [79]. In the phylogenetic works by Bleidorn and collaborators [101,168] two distinct clades of L. pugettensis were reported, one from Friday Harbor and another from Santa Monica, Northern and Southern California, respectively. Furthermore, Carr et al. [110] found five MOTUs among the Canadian populations of L. pugettensis using the DNA barcoding approach. More recently, Haggin (pers. comm.) detected at least six morphotypes showing a different pattern of depth distribution. Another 
widespread species from Western North America (i.e., Scoloplos acmeceps) showed to have at least three clades (Morro Bay and Friday Harbor from Northern California, and Newport from Rhode Island) by means of the molecular analyses of Bleidorn et al. [101]. Similarly to L. pugettensis, Haggin (pers. comm.) detected at least two different morphotypes of S. acmeceps coexisting in the intertidal and the shelf $(<200 \mathrm{~m})$ areas in Southern California.

Naineris dendritica is frequently sampled in the intertidal sands and muds along the Californian coast $[79,178]$ and is also recorded in the Pacific North America, the Arctic Canada and the Gulf of Mexico (see Table S1 in Supplementary Materials for details). Carr et al. [110] reported four MOTUs among the British Columbia and the Arctic Canada, with a high divergent clustering in the British Columbia. Additionally, Zhadan et al. [102], using some of the published sequences from Carr et al. [110] and previous works of Bleidorn and collaborators $[19,101]$, found significant genetic dissimilarity between two Southern Californian specimens according to the $16 \mathrm{~S}$ NJ tree (Figure 6C) and a high genetic distance between one Southern Californian specimen and the Canadian populations according to the COI NJ Tree (Figure 6D).

Leitoscoloplos mammosus, described from Loch Creran (Scotland) by Mackie [96], is morphologically very similar to Leitoscoloplos acutus, described from Massachusetts, USA, and was later recorded from North Carolina to Canadian Arctic and also in the White Sea, Russia $[179,180]$. In recent years, several records of both L. mammosus, from Iceland, The Channel and the North and the Norwegian Seas, and L. acutus, from the Barents and the Kara Seas, have been reported (pers. obs. by the authors; Andy Mackie, pers. comm.; OBIS, https: / / obis.org/taxon/607421 and https:/ / obis.org/taxon/130514; GBIF, https:/ /www. gbif.org/species / 4289003 and https: / /www.gbif.org/species/2319969). Morphological comparison of materials from the type locality together with molecular studies should help to resolve the relationships and validity of the two species.

Several subspecies were recorded for Orbiniidae, but none of them has been verified by genetic analyses. Phylo foetida is the orbiniid with the most documented subspecies (seven, see Table S1 in Supplementary Materials). The species was initially described from the Gulf of Naples (Italy) and later reported, together with the distinct subspecies, from several localities around the Mediterranean Sea, Gulf of Biscay, English Channel as well as from Mozambique, Madagascar and Libia in Africa [181]. Bleidorn et al. [101] found significant genetic dissimilarity between two distinct specimens of $P$. foetida from Sardinia (Mediterranean) and Arcachon (Gulf of Biscay). The remaining reported subspecies are Scoloplos acmeceps profundus Hartman, 1960 [182], Phylo felix asiaticus Wu, 1962 [124] and Leodamas chevalieri candensis Harmelin, 1969 [162].

\subsection{Ecology}

\subsubsection{Habitat}

Orbiniids are burrowing deposit-feeding annelids which live in soft bottoms rich in organic matter. They are strictly known from marine waters though some taxa, such as Naineris laevigata (Grube, 1855) [183], Scoloplos capensis (Day, 1961) [184] or Scoloplos marsupialis (Southern, 1921) [185], are quite tolerant to low salinity $[159,186,187]$. Orbiniidae can be found in a wide variety of sediments, as in mud (Figure 11A,B), sand (Figure 11C,D), mud or sand with shell fragments, mixed bottoms with stones or annelid reefs (Figure $11 \mathrm{E}$ ), bivalve beds or in algal meadows (Figure 11F,G). The large-sized genera (as Scoloplos and Leitoscoloplos) are usually recorded from intertidal and shallow muddy bottoms, except for Orbinia, which prefers sandy sediments, and Califia, mostly reported from deep waters. The small-sized genera (as Protoariciella and Protoaricia), together with Naineris, are often encountered among algal holdfasts, with the exception of Questa and the deep-sea genera Berkeleyia and Microrbinia, which have never been reported in algal congregations. Although Orbiniella is mainly deep sea, some shallow species inhabits algal groupings, as $O$. spinosa or O. plumisetosa Buzhinskaya, 1993 [139]. The interstitial Questa live in coarse, fine and coralline sands from shallow waters. The monotypic genera Paraorbiniella, Pararicia and Uncorbinia were reported from littoral zones and have not been documented again since 
their original description (see Table S1 in Supplementary Materials for details). The species inhabiting the intertidal are tolerant to hypoxic conditions through several adaptations. However, S. cf. armiger showed only moderate resistance to anoxia in the Wadden Sea, and individuals actively ascends to oxidative layers during low tides [188]. In contrast, the coexistent Arenicola marina (Linnaeus, 1758) [189] can inhabit deeper sediment layers by means of a more efficient anaerobic metabolism. Leitoscoloplos mammosus is a dominant macrofauna species in the anoxic mud of the Upper Basin of Loch Creran (Scotland), an area with strong accumulations of detritus (Andy Mackie, pers. comm.). The most hypoxic habitats inhabited by Orbiniidae are abyssal plains (with 16 recorded species), hydrothermal vents (i.e., Leitoscoloplos sahlingi Blake, 2020, Orbiniella hobsonae Blake and Hilbig, 1990 [138] and Orbiniella grasslei Blake, 2020) and hydrocarbon seeps (i.e., Methanoaricia dendrobranchiata). This last species lives in association with the bivalve Gigantidas childressi (Gustafson, R. D. Turner, Lutz and Vrijenhoek, 1998) [190] as an adaptation to the hydrocarbon enriched sediments on the Louisiana continental slope (Gulf of Mexico). Other adaptations of this orbiniid to this extreme habitat are described and compiled elsewhere [6,191-193].
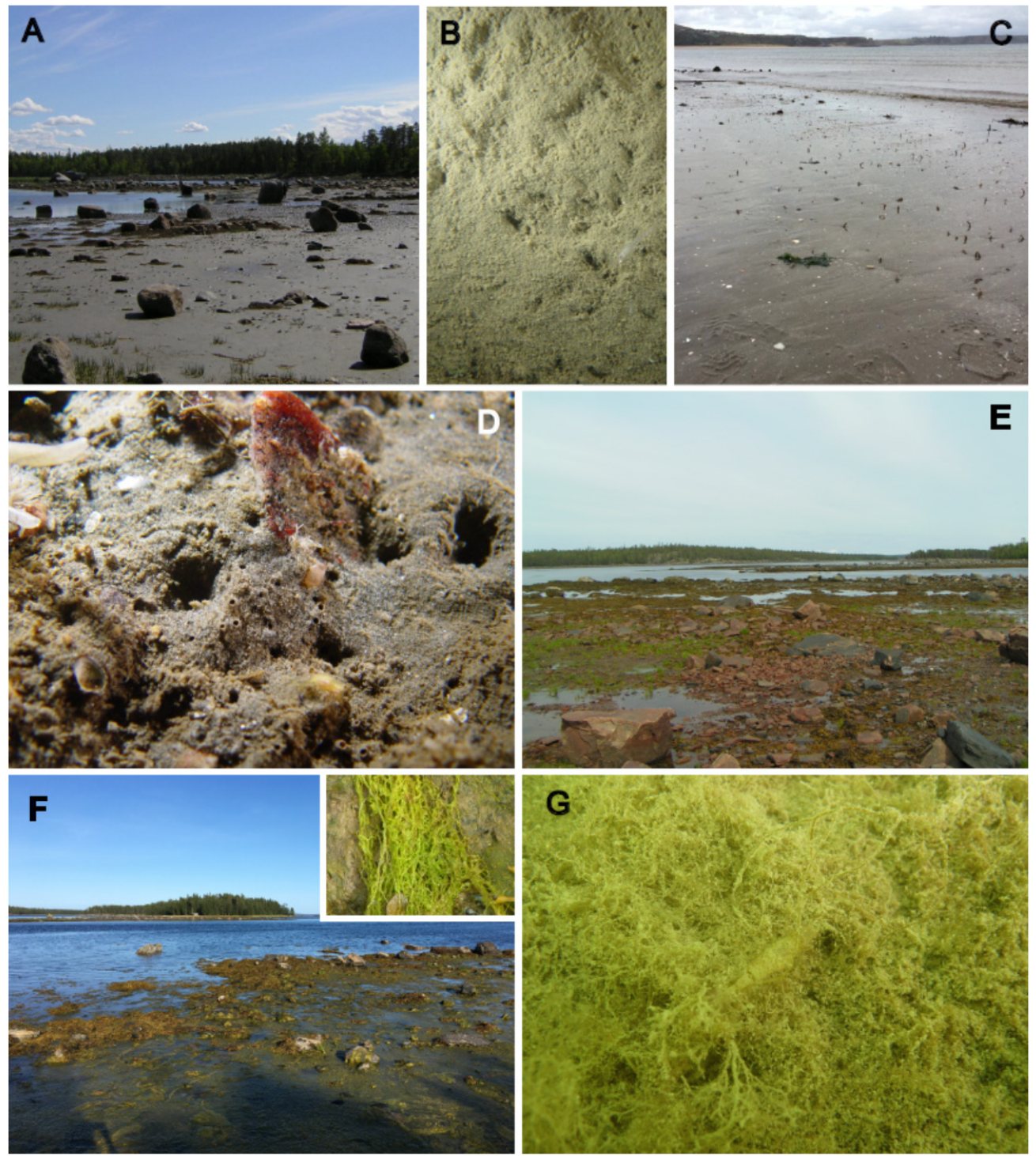

Figure 11. Photographs of some common and special habitats in Orbiniidae. (A). Muddy intertidal. (B). Muddy subtidal. (C). Sandy intertidal. (D). Sandy subtidal. (E) Mixed muddy/rocky intertidal. (F). Intertidal algal meadow, with detail on the algal species Ulva sp. (G). Subtidal algal meadow (different filamentous algae). All photos were taken from the White Sea, Russia, except $\mathbf{C}$ which was taken from Oxwich Bay, Wales. 
Traditionally, the description of a new orbiniid species is not accompanied by the description of its habitat, which are relevant data for species delimitation according to the Integrative Taxomony concept [118,194-196]. Furthermore, it is crucial to resample certain areas, especially type localities. We encourage researchers to include data on the habitat of the species in ongoing work.

\subsubsection{Relation to Pollution}

Although orbiniids have not been traditionally used as bioindicators, some species (e.g., Scoloplos cf. armiger and Scoloplos madagascarensis Fauvel, 1919 [197] in Reunion Islands, Eastern Madagascar) increase in density under the presence of pollutants, showing the potential of their use as indicators of disturbance or nonpollution. These species were referred to ecological group III "Species tolerant to excess of organic matter" according to the AMBI biotic index [198], as their populations were stimulated by discharges of industrial wastes in their natural habitat [199]. Similarly, Leitoscoloplos pugettensis in Southern California marine bays was referred to group III by Teixeira et al. [200]. An interesting case is that of Leitoscoloplos fragilis (Verrill, 1873) [169], which showed tissue accumulation of the hydrocarbon Benzo(a)pyrene under high exposures without effects on mortality [201], making it tolerant to and indicator of Polycyclic Aromatic Hydrocarbons contamination.

Other orbiniids are sensitive to high concentrations of pollutants, decreasing their density or disappearing completely from the environment. For instance, Leitoscoloplos foliosus (Hartman, 1951) [202] revealed to be sensitive and an indicator of low metals and low/moderate organic pollution in Northern Gulf of Mexico estuaries [203]. Scoloplos cf. armiger and Scoloplos typicus (Eisig, 1914) [93] are referred to ecological group I "Species very sensitive to organic enrichment and present under unpolluted conditions" in the Cantabrian Sea (Northern Spain) [198]. In a domestic sewage impact study in the macrofaunal composition of several intertidal mussel beds of Mar de la Plata (Argentina) [204], Protoariciella uncinata was subdominant in a control unpolluted station and disappeared in the most impacted station.

\subsection{Conclusions}

Orbiniidae are common and often abundant in bottom communities. In spite of a long history of investigations, many aspects of their morphology, biology, systematics and phylogeny remain poorly known. We can suggest several directions of topical future research. The main approach should be integrative taxonomy combining morphological, molecular and biological data. For many species, re-examination of type specimens or designating of neotypes is required as well as thorough investigations of specimens from different geographical areas. Preferably these studies should include scanning electron microscopy for revealing fine details of chaetal and ciliation patterns. Other techniques, such as histological sections or confocal microscopy can be useful for examination of chaetal arrangement. The phylogenetic system of Orbiniidae requires advanced genetic studies, including new technologies such as next generation sequencing, in combination with morphological examinations of the well-supported clades in search of possible new informative characters. Taxon coverage of molecular based studies should be expanded considerably. Obtaining genetic information for type species of each genus is crucial; specimens for genetic analysis should be collected from the type localities. For species with wide geographical distribution, population genetic studies are necessary to reveal cryptic species. Studies of postlarval development will help researchers to understand the transformations of morphological structures during ontogenesis and the progenetic evolution of orbiniids. Morphofunctional observations and experimental research of burrowing will possibly shed light on the function of different types of chaetae and other parapodial structures.

Supplementary Materials: The following are available online at https: / / www.mdpi.com/1424-281 8/13/1/29/s1, Table S1: Species table, Table S2: Summary table. 
Author Contributions: The three authors contributed to the conceptualization, investigation and writing (both for the original draft and review and editing) in the following order: M.A.M., T.H.S. and A.Z. All authors have read and agreed to the published version of the manuscript.

Funding: A.Z. was funded by grants from the Russian Foundation of Basic Research no. 18-05-60158, 19-04-00501.

Data Availability Statement: No new data were created or analyzed in this study. Data sharing is not applicable to this article.

Acknowledgments: We greatly acknowledge the text revision and comments made on previous versions of this Manuscript by Nataliya Budaeva. Christoph Bleidorn made inputs on orbiniid knowledge and provided Figure 5G. We also would like to thank the original photographs provided by Katrine Kongshavn (Figure 5H), Kate Mortimer and Andrew S. Y. Mackie (Figure 11C), the bibliography contributed by João Gil and Verônica Oliveira, and the shared knowledge on the Californian orbiniid morphotypes and on the orbiniid species distribution from NE Pacific by Brent Haggin and Leslie Harris.

Conflicts of Interest: The authors declare no conflict of interest.

\section{References}

1. Fauchald, K. The polychaete worms. Definitions and keys to the orders, families and genera. Nat. Hist. Mus. Los Angeles Cty. 1977, 28, 188.

2. Fauvel, P. Polychètes Sédentaires. Addenda aux Errantes, Archiannélides, Myzostomaires. Faune Fr. 1927, 16, 1-494.

3. Day, J.H. A Monograph on the Polychaeta of South Africa. Part 2. Sedentaria.; British Museum (Natural History): London, UK, 1967.

4. Hartmann-Schröder, G. Teil 58. Annelida, Borstenwürmer, Polychaeta; VEB Gustav Fischer Verlag: Jena, Germany, 1971.

5. Rouse, G.W.; Fauchald, K. Cladistics and polychaetes. Zoöl. Scr. 1997, 26, 139-204. [CrossRef]

6. Bleidorn, C.; Helm, C. 7.1.4 Orbiniidae Hartman, 1942. In Annelida Basal Groups and Pleistoannelida; Sedentaria, I., Purschke, G., Böggemann, M., Westheide, W., Eds.; De Gruyter: Berlin/Boston, Germany, 2019; pp. 237-250. [CrossRef]

7. Struck, T.H. 7.2 Phylogeny. In Annelida Basal Groups and Pleistoannelida; Sedentaria, I., Purschke, G., Böggemann, M., Westheide, W., Eds.; De Gruyter: Berlin/Boston, Germany, 2019; pp. 37-68. [CrossRef]

8. Struck, T.H.; Paul, C.; Hill, N.; Hartmann, S.; Hösel, C.; Kube, M.; Lieb, B.; Meyer, A.; Tiedemann, R.; Purschke, G.; et al. Phylogenomic analyses unravel annelid evolution. Nat. Cell Biol. 2011, 471, 95-98. [CrossRef]

9. Struck, T.H. The Impact of Paralogy on Phylogenomic Studies-A Case Study on Annelid Relationships. PLoS ONE 2013, 8, e62892. [CrossRef]

10. Weigert, A.; Bleidorn, C. Current status of annelid phylogeny. Org. Divers. Evol. 2016, 16, 345-362. [CrossRef]

11. Martín-Durán, J.M.; Vellutini, B.C.; Marlétaz, F.; Cetrangolo, V.; Cvetesic, N.; Thiel, D.; Henriet, S.; Grau-Bové, X.; CarrilloBaltodano, A.M.; Gu, W.; et al. Conservative route to genome compaction in a miniature annelid. Nat. Ecol. Evol. 2020, 1-12. [CrossRef]

12. Struck, T.H.; Golombek, A.; Weigert, A.; Franke, F.A.; Westheide, W.; Purschke, G.; Bleidorn, C.; Halanych, K.M. The Evolution of Annelids Reveals Two Adaptive Routes to the Interstitial Realm. Curr. Biol. 2015, 25, 1993-1999. [CrossRef]

13. Worsaae, K.; Kristensen, R.M. Evolution of interstitial Polychaeta (Annelida). Hydrobiologia 2005, 535, 319-340. [CrossRef]

14. Struck, T.H.; Purschke, G.; Dordel, J.; Hösel, C.; Nesnidal, M.P.; Diersing, F.; Bleidorn, C.; Paul, C.; Hill, N.; Tiedemann, R.; et al. Phylogeny and evolution of Annelida based on molecular data. In Deep Metazoan Phylogeny: The Backbone of the Tree of Life-New Insights from Analyses of Molecules, Morphology, and Theory of Data Analysis; Wägele, J.W., Bartolomaeus, T., Eds.; De Gruyter: Berlin, Germany, 2014; pp. 143-160.

15. Struck, T.H.; Nesnidal, M.; Purschke, G.; Halanych, K.M. Detecting possibly saturated positions in $18 \mathrm{~S}$ and $28 \mathrm{~S}$ sequences and their influence on phylogenetic reconstruction of Annelida (Lophotrochozoa). Mol. Phylogenet. Evol. 2008, 48, 628-645. [CrossRef]

16. Jordens, J.; Struck, T.; Purschke, G. Phylogenetic inference regarding Parergodrilidae and Hrabeiella periglandulata ('Polychaeta', Annelida) based on 18S rDNA, 28S rDNA and COI sequences. J. Zoöl. Syst. Evol. Res. 2004, 42, 270-280. [CrossRef]

17. Struck, T.H.; Hessling, R.; Purschke, G. The phylogenetic position of the Aeolosomatidae and Parergodrilidae, two enigmatic oligochaete-like taxa of the 'Polychaeta', based on molecular data from $18 S$ rDNA sequences. J. Zoöl. Syst. Evol. Res. 2002, 40, 155-163. [CrossRef]

18. Bleidorn, C. The role of character loss in phylogenetic reconstruction as exemplified for the Annelida. J. Zoöl. Syst. Evol. Res. 2007, 45, 299-307. [CrossRef]

19. Bleidorn, C. Phylogenetic relationships and evolution of Orbiniidae (Annelida, Polychaeta) based on molecular data. Zoöl. J. Linn. Soc. 2005, 144, 59-73. [CrossRef]

20. Bleidorn, C.; Vogt, L.; Bartolomaeus, T. New insights into polychaete phylogeny (Annelida) inferred from $18 \mathrm{~S}$ rDNA sequences. Mol. Phylogenet. Evol. 2003, 29, 279-288. [CrossRef]

21. Zrzavý, J.; Riha, P.; Piálek, L.; Janouškovec, J. Phylogeny of Annelida (Lophotrochozoa): Total-evidence analysis of morphology and six genes. BMC Evol. Biol. 2009, 9, 189. [CrossRef] 
22. Reisinger, E. Ein landbewohnender archiannelide. Zoomorphology 1925, 3, 197-254. [CrossRef]

23. Meyer, A. Ist Parergodrilus heideri (Reisinger) ein Archiannelide? Zool. Anz. 1927, 72, 19-35.

24. Karling, T.G. Zur Kenntnis von Stygocapitella subterranea Knöllner und Parergodrilus heideri Reisinger. Ark. Zool. 1958, 1, 307-324.

25. Knöllner, F. Stygocapitella subterranea nov.gen., nov.spec. Schriften Naturwissenschaftlichen Ver. Schlesw. Holst. 1934, $20,468-472$.

26. Hartmann-Schröder, G. Teil 58. Annelida, Borstenwürmer, Polychaeta, 2nd ed.; Gustav Fischer: Stuttgart, Germany, 1996.

27. Pizl, V.; Chalupsky, J. Hrabeiella periglandulata gen. et sp. n.(Annelida): A curious worm from Czechoslovakia. Veštn. Českoslov. Spol. Zool. 1984, 48, 291-295.

28. Rota, E. Morphology and adaptations of Parergodrilus Reisinger and Hrabeiella Pizl \& Chalupsky, two enigmatic soil-dwelling annelids. Ital. J. Zoöl. 1998, 65, 75-84. [CrossRef]

29. Purschke, G. Male genital organs, spermatogenesis and spermatozoa in the enigmatic terrestrial polychaete Parergodrilus heideri (Annelida, Parergodrilidae). Zoomorphology 2002, 121, 125-138. [CrossRef]

30. Purschke, G. Terrestrial polychaetes-Models for the evolution of the Clitellata (Annelida)? Hydrobiologia 1999, 406, 87-99. [CrossRef]

31. Rota, E.; De Nicola, F.; Bargagli, R. Parergodrilus heideri Reisinger, 1925 (Annelida: Polychaeta) from a holm oak wood in an extinct volcano of southern Italy. Zootaxa 2010, 2687, 65-68. [CrossRef]

32. Rota, E. First Italian record of the terrestrial polychaeteparergodrilus heiderireisinger, with anatomical and ecological notes. Ital J. Zoöl. 1997, 64, 91-96. [CrossRef]

33. Reisinger, E. Die Lösung des Parergodrilus-Problems. Z. Morphol. Ökol. Tiere 1960, 48, 517-544. [CrossRef]

34. Graefe, U. Die Gliederung der Zersetzergesellschaften für die standortsökologische Ansprache. Mitteilungen Dtsch. Bodenkd. Ges. 1993, 69, 95-98.

35. Graefe, U.; Schmelz, R.M. Indicator values, strategy types and life forms of terrestrial Enchytraeidae and other microannelids. In Newsletter on Enchytraeidae 6, Proceedings of the 3rd International Symposium on Enchytraeidae, Osnabrïck, Germany, 3-4 July 1998; Schmelz, R.M., Sühlo, K., Eds.; Universitätsverlag Rasch: Osnabrück, Germany, 1999; pp. 59-67.

36. Martinez-Ansemil, E.; Parapar, J. Primera cita en la península Ibérica del poliqueto terrestre Parergodrilus heideri Reisinger, 1925 (Polychaeta, Parergodrilidae). Graellsia 2009, 65, 235-240. [CrossRef]

37. Schlaghamerský, J.; Frelich, L.E. First records of Parergodrilus heideri (Annelida: "Polychaeta") from North America. Zootaxa 2012, 3498, 81-86. [CrossRef]

38. Rota, E.; De Jong, Y. Fauna Europaea: Annelida-Terrestrial Oligochaeta (Enchytraeidae and Megadrili), Aphanoneura and Polychaeta. Biodivers. Data J. 2015, 3, e5737. [CrossRef] [PubMed]

39. Römbke, J.; Jans, W. On terrestrial Polychaeta (Annelida) from forest soils of southern Germany. Verhandlungen Dtsch. Zool. Ges. 1991, 84, 447-448.

40. Beylich, A.; Graefe, U. Investigations on the enchytraeid fauna in floodplain soils of the Lower Middle Elbe. Folia Fac. Sci. Nat. Univ. Masaryk. Brun. Brno Biol. 2007, 110, 107-122.

41. Chalupský, J. Terrestrial Enchytraeidae (Oligochaeta) and Parergodrilidae (Polychaeta) from Sweden, with description of a new enchytraeid species. Zool. Scr. 1992, 21, 133-150. [CrossRef]

42. Rouse, G.W.; Pleijel, F. Polychaetes; Oxford University Press: New York, NY, USA, 2001; p. 354.

43. Purschke, G. Problematic Annelid Groups. In Reproductive Biology and Phylogeny of Annelida; Rouse, G.W., Pleijel, F., Eds.; Science Publisher: Plymouth, UK, 2006; Volume 4, pp. 639-667.

44. Westheide, W. Polychaetes: Interstitial Families, 2nd ed.; Field Studies Council: Shrewsbury, UK, 2008.

45. Purschke, G. 7.1.3 Parergoldrilidae Reisinger, 1925. In Annelida Basal Groups and Pleistoannelida; Sedentaria, I., Purschke, G., Böggemann, M., Westheide, W., Eds.; De Gruyter: Berlin/Boston, Germany, 2019; pp. 237-250. [CrossRef]

46. Cerca, J.; Meyer, C.; Purschke, G.; Struck, T.H. Delimitation of cryptic species drastically reduces the geographical ranges of marine interstitial ghost-worms (Stygocapitella; Annelida, Sedentaria). Mol. Phylogenet. Evol. 2020, 143, 106663. [CrossRef] [PubMed]

47. Cerca, J.; Meyer, C.; Stateczny, D.; Siemon, D.; Wegbrod, J.; Purschke, G.; Dimitrov, D.; Struck, T.H. Deceleration of morphological evolution in a cryptic species complex and its link to paleontological stasis. Evolution 2019, 74, 116-131. [CrossRef]

48. Struck, T.H.; Koczula, J.; Stateczny, D.; Meyer, C.; Purschke, G. Two new species in the annelid genus Stygocapitella (Orbiniida, Parergodrilidae) with comments on their biogeography. Zootaxa 2017, 4286, 301. [CrossRef]

49. Jans, W.; Römbke, J. Funde eines terrestrischen Polychaeten (Annelida) in Wäldern Baden-Württembergs. Carolinea 1989, 47, 158-162.

50. Rota, E.; Martin, P.; Erséus, C. Soil-dwelling polychaetes: Enigmatic as ever? Some hints on their phylogenetic relationships as suggested by a maximum parsimony analysis of $18 \mathrm{~S}$ rRNA gene sequences. Contrib. Zool. 2001, 70, 127-138. [CrossRef]

51. Dózsa-Farkas, K.; Hong, Y. Three new Hemienchytraeus species (Enchytraeidae, Oligochaeta, Annelida) from Korea, with first records of other enchytraeids and terrestrial polychaetes (Annelida). Zootaxa 2010, 2406, 29-56. [CrossRef]

52. Riser, N.W. The aberrant polychaete Stygocapitella from some American beaches. Wasmann J. Biol. 1980, 38, 10-17.

53. Westheide, W. Zur Polychaetenfauna des Eulitorals der Nordseeinsel Sylt. Helgol. Mar. Res. 1966, 13, 203-209. [CrossRef]

54. Riser, N.W. General observations on the intertidal interstitial fauna of New Zealand. Tane 1984, 30, $239-250$. 
55. Worsfold, T.M.; Dyer, M.F. UK Marine SACs Project. Monitoring Methods Workshop at Plymouth (April 1997) and Millport (May 1997). (Contractor: Unicomarine, Letchworth); Joint Nature Conservation Committee: Peterborough, UK, 1997.

56. Hartmann-Schröder, G. Teil 9-Die Polychaeten der antiborealen Südwestküste Australiens (zwischen Dunsborough im Norden und Denmark im Süden). Mitteilungen Hambg. Zool. Mus. Inst. 1983, 80, 123-167.

57. Schmidt, H.; Westheide, W. Are the meiofaunal polychaetes Hesionides arenaria and Stygocapitella subterranea true cosmopolitan species?-Results of RAPD-PCR investigations. Zool. Scr. 2000, 29, 17-27. [CrossRef]

58. Schmidt, P. Zonation of the interstitial polychaeteStygocapitella subterranea (Stygocapitellidae) in European sandy beaches. Mar. Biol. 1970, 7, 319-323. [CrossRef]

59. Schmidt, P. Die quantitative Verteilung und Populationsdynamik des Mesopsammons am Gezeiten-Sandstrand der Nordsee-Insel Sylt1). II. Quantitative Verteilung und Populationsdynamik einzelner Arten. Int. Rev. Hydrobiol. 1969, 54, 95-174. [CrossRef]

60. Westheide, W. The geographical distribution of interstitial polychaetes. Mikrofauna Meeresbod. 1977, 61, $287-302$.

61. Schmidt, P. Zonierung und jahreszeitliche Fluktuationen des Mesopsammons im Sandstrand von Schilksee (Kieler Bucht). Mikrofauna Meeresbod. 1972, 10, 1-60.

62. Schmidt, P. Zonierung und jahreszeitliche Fluktuationen der interstitiellen Fauna in Sandstränden des Gebiets von Troms $\varnothing$ (Norwegen). Mikrofauna Meeresbod. 1972, 10, 81-164.

63. Renaud-Debysier, J. Recherches écologiques sur la faune interstitielle des sables. Bassin d'Arcachon, Île de Bimini, Bahamas. Vie Milieu Suppl. 1963, 15, 1-157.

64. Valkanov, A. Zwei neue Polychaeten für das Schwarze Meer [Bulgar]. Trud. Chernomorsk. Biol. Sta. Varna 1954, $18,55-58$.

65. Westheide, W. La faune des Polychètes et des Archiannélides dans les plages à Ressac de la côte méditerranéenne de la Tunisie. Bull. Insti. Natl. Sci. Technol. Mer 1972, 2, 449-468.

66. Worsfold, T.M. British records of the interstitial polychaete Stygocapitella subterranea (Annelida: Parergodrilidae). Mar. Biodivers. Rec. 2008, 1, 40. [CrossRef]

67. Brinck, P.; Dahl, E.; Wieser, W. On the littoral subsoil fauna of the Simrishamn Beach in Eastern Scania. K. Fysiogr. Sällsk. Lund Förh. 1955, 25, 109-129.

68. Itô, T. Studies on the interstitial animals in the Ishikari beach, Hokkaido, northern Japan-A preliminary report. BENTHOS Res. 1984, 1-14. [CrossRef]

69. Westheide, W. Meiofauna geographic distribution: Vicariance and dispersal. Meiofauna Mar. 2005, 14, $201-207$.

70. Cerca, J.; Purschke, G.; Struck, T.H. Marine connectivity dynamics: Clarifying cosmopolitan distributions of marine interstitial invertebrates and the meiofauna paradox. Mar. Biol. 2018, 165, 123. [CrossRef]

71. Struck, T.H.; Feder, J.L.; Bendiksby, M.; Birkeland, S.; Cerca, J.; Gusarov, V.I.; Kistenich, S.; Larsson, K.-H.; Liow, L.H.; Nowak, M.D.; et al. Finding Evolutionary Processes Hidden in Cryptic Species. Trends Ecol. Evol. 2018, 33, 153-163. [CrossRef]

72. Gerlach, S.A. Means of meiofauna dispersal. Mikrofauna Meeresbod. 1977, 61, 89-103.

73. Hedgpeth, J.W. Polychaeta Errantia of Antarctica. Volume 3, Antarctic Research Series.Olga HartmanPolychaeta Myzostomidae and Sedentaria of the Antarctica. Volume 7, Antarctic Research Series.Olga HartmanPolychaetous Annelids Collected by the USNS Eltanin and Staten Island Cruises Chiefly from Antarctic Seas. Allan Hancock Monographs in Biology, No. 2.Olga Hartman. Q. Rev. Biol. 1968, 43, 206. [CrossRef]

74. Blake, J.A. Polychaeta Orbiniidae from Antarctica, the Southern Ocean, the Abyssal Pacific Ocean, and off South America. Zootaxa 2017, 4218, 1-145. [CrossRef] [PubMed]

75. Day, J.H. New polychaeta from Beaufort: With a key to all species recorded from North Carolina. Biodivers. Herit. Libr. 1973, 375, 1-140. [CrossRef]

76. Day, J. A review of the Australian and New Zealand Orbiniidae (Annelida: Polychaeta). In Essays on Polychaetous Annelids in Memory of Dr. Olga Hartman; Reish, D.J., Fauchald, K., Eds.; Allan Hancock Foundation: Los Angeles, CA, USA, 1977; pp. 217-243.

77. Zhadan, A. Review of Orbiniidae (Annelida, Sedentaria) from Australia. Zootaxa 2020, 4860, 451-502. [CrossRef] [PubMed]

78. Kirkegaard, J. Havborsteorme II. Sedentaria; Dansk Naturhistorisk Forening: Copenhagen, Denmark, 1996; Volume 86, p. 451.

79. Blake, J.A. Family Orbiniidae Hartman, 1942. In Taxonomic Atlas of the Benthic Fauna of Santa Maria Basin and Western Santa Barbara Channel. The Annelida Part 3-Polychaeta: Orbiniidae to Cossuridae; Blake, J.A., Hilbig, B., Scott, P.H., Eds.; Santa Barbara Museum of Natural History: Santa Barbara, CA, USA, 1996; Volume 6, pp. 1-26.

80. López, E. Familia Orbiniidae Hartman, 1942. In Fauna Iberica. Annelida Polychaeta III; Parapar, J., Alós, C., Núñez, J., Moreira, J., López, E., Aguirrezabalaga, F., Besteiro, C., Martinez, A., Eds.; Museo Nacional de Ciencias Naturales. CSIC: Madrid, Spain, 2012; Volume 36, pp. 96-160.

81. Díaz-Díaz, O.; Vanegas-Espinosa, V.; Cárdenas-Oliva, A.; Liñero-Arana, I. Orbiniidae Hartman, 1942 (Annelida: Polychaeta) de las costas de Venezuela. Biota Colomb. 2012, 13, 18-34.

82. Gillet, P. A new species of Orbiniella (Orbiniidae: Polychaeta) from Marion Island, Indian Ocean. Proc. Biol. Soc. Wash. 1999, 112, 592-597.

83. Parapar, J.; Moreira, J.; Helgason, G.V. First record of genus Orbiniella Day, 1954 (Polychaeta: Orbiniidae) in North Atlantic Ocean with the description of a new species. Zootaxa 2015, 4006, 330-346. [CrossRef]

84. Solis-Weiss, V.; Fauchald, K. Orbiniidae (Annelida: Polychaeta) from mangrove root-mats in Belize, with a revision of protoariciin genera. Proc. Biol. Soc. Wash. 1989, 102, 772-792. 
85. Sun, Y.; Li, X. Orbinia wui, a new species from China, with redescription of O. dicrochaeta Wu, 1962 (Annelida, Orbiniidae). Zootaxa 2018, 4403, 351-364. [CrossRef]

86. Sun, Y.; Sui, J.; Li, X. A new species of Leodamas Kinberg, 1866 (Polychaeta: Orbiniidae) from the Yellow Sea and the East China Sea. Acta Oceanol. Sin. 2018, 37, 130-135. [CrossRef]

87. Blake, J.A. New species and records of deep-water Orbiniidae (Annelida, Polychaeta) from the Eastern Pacific continental slope, abyssal Pacific Ocean, and the South China Sea. Zootaxa 2020, 4730, 1-61. [CrossRef] [PubMed]

88. Malmgren, A.J. Annulata Polychaeta Spetsbergiae, Groenlandiae, Islandiae et Scandinaviae hactenus cognita. Ofvers. K. Vetenskapsakademiens Forh. 1867, 24, 127-235.

89. Hartman, O. A review of the types of polychaetous annelids at the Peabody Museum of Natural History, Yale University. Bull. Bingham Oceanogr. Collect. Yale Univ. 1942, 8, 1-98.

90. Savigny, J.-C.; Benedict, J.E. Systèmes de Diverses Clases D’animaux Sans Vertèbres. Principalement de Celles des Côtes de l'Égypte et de la Syrie, Offrant les Caractères Tant Distinctifs que Naturels des Ordres, Familles et Genres, avec la Description des espèces. Available online: https:/ / www.biodiversitylibrary.org/bibliography/66284\#/summary (accessed on 18 December 2020).

91. Quatrefages, A. Note sur la Classification des Annelides. Ann. Sci. Nat. Paris 1865, 5, 253-296.

92. Hartman, O. Nomenclatural changes involving California polychaete worms. J. Wash. Acad. Sci. 1936, $26,31-32$.

93. Eisig, H. Zur Systematik, Anatomie und Morphologie der ariciiden nebst beiträgen zur generellen Systematik. Mitteilungen Zool. Station Neapel 1914, 21, 153-500.

94. Hartman, O. Orbiniidae, Apistobranchidae, Paraonidae and Longosomidae. Allan Hancock Pac. Exped. 1957, 15, $211-393$.

95. Pettibone, M.H. North American genera of the family Orbiniidae (Annelida: Polychaeta), with descriptions of new species. $J$. Wash. Acad. Sci. 1957, 47, 159-167.

96. Mackie, A.S. A review of species currently assigned to the genus Leitoscoloplos Day, 1977 (Polychaeta: Orbiniidae), with descriptions of species newly referred to Scoloplos Blainville, 1828. Sarsia 1987, 72, 1-28. [CrossRef]

97. Badalamenti, F.; Castelli, A. Schroederella laubieri, a new species of the subfamily protoariicinae (polychaeta, orbiniidae), with some notes on the genusschroederellalaubier, 1962. Boll. Zool. 1991, 58, 95-98. [CrossRef]

98. Blake, J.A. A new genus of polychaete worm (Family Orbiniidae) from methane seeps in the Gulf of Mexico, with a review of the systematics and phylogenetic interrelationships of the genera of Orbiniidae. Cah. Biol. Mar. 2000, 4, 435-449.

99. Bleidorn, C.; Vogt, L.; Bartolomaeus, T. A contribution to sedentary polychaete phylogeny using 18S rRNA sequence data. J. Zool. Syst. Evol. Res. 2003, 41, 186-195. [CrossRef]

100. Hartman, O. Quantitative survey of the benthos of SanPedro Basin, Southern California. Part 11. Final results and conclusions. Allan Hancock Pac. Exped. 1966, 19, 187-456.

101. Bleidorn, C.; Hill, N.; Erséus, C.; Tiedemann, R. On the role of character loss in orbiniid phylogeny (Annelida): Molecules vs. morphology. Mol. Phylogenet. Evol. 2009, 52, 57-69. [CrossRef] [PubMed]

102. Zhadan, A.; Stupnikova, A.N.; Neretina, T. Orbiniidae (Annelida: Errantia) from Lizard Island, Great Barrier Reef, Australia with notes on orbiniid phylogeny. Zootaxa 2015, 4019, 773-801. [CrossRef] [PubMed]

103. Hartmann-Schroeder, G. Zweiter Beitrag zur Polychaetenfauna von Peru. Kiel. Meeresforsch. 1962, 18, $109-147$.

104. Ehlers, E. Ergebnisse der Hamburger Magalhaensischen Sammelreise 1892/93; L. Friederichsen \& Co.: Hamburg, Germany, $1897 ;$ p. 148.

105. Hernández-Alcántara, P.; Solís-Weiss, V. Anatomical and morphometric analysis of a new species of Leitoscoloplos (Annelida: Orbiniidae) with numerous stomach papillae, from the Gulf of California, Eastern Pacific. Contrib. Zool. 2014, 83, 133-150. [CrossRef]

106. Verrill, A.E. Additions to the Turbellaria, Nemertina, and Annelida of the Bermudas, with revisions of some New England genera and species. Trans. Connect. Acad. Arts Sci. 1900, 10, 595-671. [CrossRef]

107. Leão, L.S.D.; Santos, C.S.G. Orbinia (Polychaeta: Orbiniidae) from the Brazilian coast: Two new species and two new records. Zootaxa 2016, 4105, 145-158. [CrossRef]

108. Kruse, I.; Reusch, T.B.; Schneider, M.V. Sibling species or poecilogony in the polychaete Scoloplos armiger? Mar. Biol. 2003, 142, 937-947. [CrossRef]

109. Meyer, A.; Bleidorn, C.; Rouse, G.W.; Hausen, H. Morphological and molecular data suggest a cosmopolitan distribution of the polychaete Proscoloplos cygnochaetus Day, 1954 (Annelida, Orbiniidae). Mar. Biol. 2007, 153, 879-889. [CrossRef]

110. Carr, C.M.; Hardy, S.M.; Brown, T.M.; Macdonald, T.A.; Hebert, P.D.N. A Tri-Oceanic Perspective: DNA Barcoding Reveals Geographic Structure and Cryptic Diversity in Canadian Polychaetes. PLoS ONE 2011, 6, e22232. [CrossRef] [PubMed]

111. Hoffmann, S.; Hausen, H. Chaetal arrangement in Orbiniidae (Annelida, Polychaeta) and its significance for systematics. Zoomorphology 2007, 126, 215-227. [CrossRef]

112. Hartmann-Schröder, G. Zur Kenntnis des eulitorals der australischen Kuesten unter besounderer Beruecksichtigung des Polychaeten und Ostracoden. Teil 16. Die Polychaeten der subtropisch-tropischen bis tropischen Ostkueste Australiens zwischen Maclean (New South Wales) und Gladstone (Queensland) sowie von Heron Island (Grosses Barrier Riff). Mitteilungen Hamburgischen Zool. Mus. Inst. 1991, 88, 17-71.

113. Kinberg, J. Annulata nova. Ofversight K. Vetensk.-Adakemiens Forh. Stockh. 1866, 22, 239-258.

114. Tebble, N. The polychaete fauna of the Gold Coast [=Ghana]. Bulletin of the British Museum (Natural History), Ser. Zoology 1955, $3,59-148$. 
115. De Oliveira, V.M.; Cutrim, A.S.T.; Vieira, A.K.M.; Ferreira, C.N.; Almeida, Z.S.; Júnior, M.N. Description of Scoloplos maranhensis sp. nov. (Orbiniidae, Annelida) from tropical Brazilian mangrove. Iheringia. Série Zool. 2019, 109. [CrossRef]

116. Merz, R.A. Polychaete chaetae: Function, fossils, and phylogeny. Integr. Comp. Biol. 2006, 46, 481-496. [CrossRef]

117. Martin, D.; Meca, M.A.; Gil, J.; Drake, P.; Nygren, A. Another brick in the wall: Population dynamics of a symbiotic species of Oxydromus (Annelida, Hesionidae), described as new based on morphometry. Contrib. Zool. 2017, 86, 181-211. [CrossRef]

118. Meca, M.A.; Drake, P.; Martin, D. Does polyxenous symbiosis promote sympatric divergence? A morphometric and phylogeographic approach based on Oxydromus okupa (Annelida, Polychaeta, Hesionidae). Contrib. Zool. 2019, 88, 1-28. [CrossRef]

119. Teixeira, M.A.L.; Vieira, P.E.; Pleijel, F.; Sampieri, B.R.; Ravara, A.; Costa, F.O.; Nygren, A. Molecular and morphometric analyses identify new lineages within a large Eumida (Annelida) species complex. Zool. Scr. 2019, 49, 222-235. [CrossRef]

120. Lattig, P.; Martín, G.S.; Martin, D. Análisis toxinómico y morfométrico del completo Haplosyllis spongicola (Polychaeta: Syllidae: Syllinae) de los mares de España, con la re-descripción de la especie tipo y la descripción de dos nuevas especies. Sci. Mar. 2007, 71, 551-570. [CrossRef]

121. Coutinho, M.C.L.; Paiva, P.C.; Santos, C.S.G. Morphometric analysis of two sympatric species ofPerinereis (Annelida: Nereididae) from the Brazilian coast. J. Mar. Biol. Assoc. U. K. 2015, 95, 953-959. [CrossRef]

122. Monro, C.C.A. The Polychaeta Sedentaria collected by Dr. C. Crossland at Colón, in the Panama Region, and the Galapagos Islands during the Expedition of the S.Y. 'St. George'. Proc. Zool. Soc. Lond. 2009, 103, 1039-1092. [CrossRef]

123. Müller, O.F.; Dall, W.H. Zoologiae Danicae Prodromus, seu, Animalium Daniae et Norvegiae Indigenarum Characteres, Nomina, et Synonyma Imprimis Popularium. Available online: https://www.biodiversitylibrary.org/bibliography/13268\#/summary (accessed on 18 December 2020).

124. Wu, B. New species of polychaete worms of the family Orbiniidae and Paraonidae from the Yellow Sea. Acta Zool. Sin. 1962, 14, 421-426.

125. Hartmann-Schröder, G. Die Polychaeten des Sublitorals. zur Kentnnis des Sublitorals der chilenischen Küste unter besonderer Berücksichtigung der Polychaeten und Ostracoden (Mit Bemerkungen über den Einfluss sauerstoffarmer strömungen auf die Besiedlung von marinen Sedimenten). Mitteilungen Hamburg. Zool. Mus. Inst. 1965, 62, 59-305.

126. Gallardo, V.A. Polychaeta from the bay of Nha Trang, South Viet Nam. NAGA Rep. 1968, 4, 91-96.

127. Fauchald, K. Benthic polychaetous annelids from deep water off western Mexico and adjacent areas in the eastern Pacific Ocean. Allan Hancock Monogr. Mar. Biol. 1972, 7, 162-171.

128. Maciolek, N.J.; Holland, J. Scoloplos texana: A new orbiniid polychaete from south Texas, with notes on the related species Scoloplos treadwelli Eisig. Contrib. Mar. Sci. 1978, 21, 163-169.

129. Hartmann-Schröder, G. Die Polychaeten der tropischen Nordwestküste Australiens (zwischen Derby im Norden und Port Hedland im Süden). Mitteilungen Hamburgisch. Zool. Mus. Inst. 1979, 76, 77-218.

130. Hartmann-Schröder, G. des Eulitorals der australischen Küsten unter besonder Berücksichtigung der Polychaeten und Ostracoden. Mitteilungen Hamburgisch. Zool. Mus. Inst. 1980, 77, 67-68.

131. Hartmann-Schröder, G. Zur Kenntnis des Eulitorals der australischen Kusten unter besonderer Berucksichtigung der Polychaeten und Ostracoden. Teil 6. Die Polychaeten der tropisch-subtropischen Westkuste Australiens (zwischen Exmouth im Norden und Cervantes im Suden). Mitteilungen Hamburgisch. Zool. Mus. Inst. 1981, 78, 48-49.

132. Hartmann-Schröder, G. Zur Polychaetenfauna der Polynesischen Inseln Huahiné (Gesellschafts inseln) und Rangiroa (TuamotuInseln). Mitteilungen Hamburgisch. Zool. Mus. Inst. 1992, 89, 68.

133. Mohammad, M. Polychaete annelids from Kuwaitian islands, Arabian Gulf, with descriptions of four new species. Zool. J. Linn. Soc. 1980, 69, 31-42. [CrossRef]

134. Westheide, W. Interstitielle Fauna von Galapagos. XXVI. Questidae, Cirratulidae, Acrocirridae, Ctenodrilidae (Polychaeta). Mikrofauna Meeresbod. 1981, 82, 6-8.

135. Jamieson, B.; Webb, R. The morphology, spermatozoal ultrastructure and phylogenetic affinities of a new species of questid (Polychaeta, Annelida). In Proceedings of the 1st International Polychaete Conference, Sydney, Australia, 1-5 August 2016; Linnean Society of New South Wales: Sydney, Australia, 2016; pp. 21-34.

136. Blake, J.A. Polychaeta from the vicinity of deep-sea geothermal vents in the eastern Pacific. I. Euphrosinidae, Phyllodocidae, Hesionidae, Nereididae, Glyceridae, Dorvilleidae, Orbiniidae, and Maldanidae. Bull. Biol. Soc. Wash. 1985, 6, 67-101.

137. Mackie, A.S. A new species of Scoloplos (Polychaeta: Orbiniidae) from Hong Kong and a comparison with closely related Scoloplos marsupialis Southern, 1921 from India. Asian Mar. Biol. 1991, 8, 35-44.

138. Blake, J.A.; Hilbig, B. Polychaeta from the vicinity of deep-sea hydrothermal vents in the Eastern Pacific Ocean. II. New species and records from the Juan de Fuca and Explorer Ridge systems. Pac. Sci. 1990, 44, 219-253.

139. Buzhinskaya, G.N. Occurrence of Orbiniella plumisetosa sp. n. (Polychaeta: Orbiniidae) in the north-western Pacific Ocean and a key to species of the genus Orbiniella. Explor. Fauna Seas 1993, 43, 76-81.

140. Branch, M.L. Four new species of Polychaeta from subantarctic Marion Island. Ann. S. Afr. Mus. 1998, 105, $249-265$.

141. Giere, O.; Erséus, C. A systematic account of the Questidae (Annelida, Polychaeta), with description of new taxa. Zool. Scr. 1998, 27, 345-360. [CrossRef]

142. Mirsa, A. Polychaete [Fauna of West Bengal]. In Zoological Survey of India, Calcutta, Series 3; State Fauna Series, Fauna of West Bengal, Part 10, Invertebrates; Gosh, A.K., Ed.; Zoological survey of India: Calcuttam, India, 1999; pp. 125-225.

143. Rouse, G.W. Orbiniidae Hartman, 1942. In Polychaetes; Rouse, G., Pleijel, F., Eds.; University Press: Oxford, UK, 2001 ; pp. 57-60. 
144. Eibye-Jacobsen, D. The Orbiniidae (Annelida: Polychaeta) of the BIOSHELF Project, Andaman Sea, Thailand. Phuket Mar. Biol. Cent. Spec. Publ. 2002, 24, 77-99.

145. López, E.; Cladera, P.; Martín, G.S.; Lpez, E.; Martn, G.S. Two new species of the genus Leodamas (Orbiniidae: Scolecida: Polychaeta) from the Pacific coast of Panama. J. Mar. Biol. Assoc. U. K. 2003, 83, 367-374. [CrossRef]

146. López, E.; Cladera, P.; San Martín, G. Orbiniidae polychaetes (Polychaeta: Scolecida) from Coiba Island, eastern Pacific of Panama, with description of a new species. Rev. Biol. Trop. 2006, 54, 1307-1318. [CrossRef] [PubMed]

147. Narayanaswamy, B.E.; Blake, J.A. A new species of Orbiniella (Polychaeta: Orbiniidae) from deep basins of Antarctica. J. Mar. Biol. Assoc. U. K. 2005, 85, 843-846. [CrossRef]

148. Giere, O.; Ebbe, B.; Erseus, C. Questa (Annelida, Polychaeta, Orbiniidae) from Pacific regions-New species and reassessment of the genus Periquesta. Org. Divers. Evol. 2008, 7, 304-319. [CrossRef]

149. Imajima, M. Deep-sea benthic polychaetes off Pacific coast of the northern Honshu, Japan. In Deep-Sea Fauna and Pollutants off Pacific Coast of Northern Japan; Fujita, T., Ed.; National Museum of Nature and Science Monographs: Tokyo, Japan, 2009; Volume 39, pp. 39-192.

150. Gopal, A.; Useph, A.J.K.; Varghese, S.A.; Narayana, S.V. A new species of polychaete, Pettibonella shompenssp. nov. (Orbiniidae), from the Nicobar Islands, North Indian Ocean. Mar. Biol. Res. 2014, 10, 1033-1037. [CrossRef]

151. Dean, H.K.; Blake, J.A. The Orbiniidae (Annelida: Polychaeta) of Pacific Costa Rica. Zootaxa 2015, 3956, 183-198. [CrossRef]

152. Blake, J.A. Life history analysis of five dominant infaunal polychaete species from the continental slope off North Carolina. J. Mar. Biol. Assoc. U. K. 1993, 73, 123-141. [CrossRef]

153. Fabricius, O. Fauna Groenlandica, systematice sistens, Animalia Groenlandiae occidentalis hactenus indagata, quoad nomen specificum, triviale, vernaculumque; synonyma auctorum plurium, descriptionem, locum, victum, generationem, mores, usum, capturamque singuli; prout detegendi occasion fuit, maximaque parti secundum proprias observationes. Hafniae Lipsiae 1780, $i-x v i, 1-452$.

154. Sars, G.O. Diagnoser af nye Annelider fra Christianiaforden, efter Professor M. Sar's efterladte Manuskripter. Forh. Vidensk. Christiania 1872, 1871, 406-417.

155. Claparède, É. Glanures zootomiques parmi les annélides de Port-Vendres (Pyrénées Orientales). Mém. Société Phys. d'Histoire Nat. Genève 1864, 17, 463-600.

156. Day, J.H. The Polychaeta of Tristan da Cunha. Results Nor. Sci. Exped. Tristan Cunha 1954, 29, 1-35.

157. Blake, J.A.; Giangrande, A. Naineris setosa (Verrill) (Polychaeta, Orbiniidae), an American subtropical-tropical polychaete collected from an aquaculture facility in Brindisi (Adriatic Sea, Italy): A possible alien species. Ital. J. Zool. 2011, 78, 20-26. [CrossRef]

158. Khedhri, I. First record of Naineris setosa (Verrill, 1900) (Annelida: Polychaeta: Orbiniidae) in the Western Mediterranean Sea. BioInvasions Rec. 2014, 3, 83-88. [CrossRef]

159. Raman, A.; Ganapati, P. Occurrence of Scolaricia capensis Day, 1961 (Polychaeta: Orbiniidae) off the east coast of India, Bay of Bengal. Indian J. Mar. Sci. 1977, 6, 185-186.

160. Zenetos, A.; Gofas, S.; Verlaque, M.; Cinar, M.; Raso, J.G.; Bianchi, C.; Morri, C.; Azzurro, E.; Bilecenoglu, M.; Froglia, C.; et al. Alien species in the Mediterranean Sea by 2010. A contribution to the application of European Union's Marine Strategy Framework Directive (MSFD). Part I. Spatial distribution. Mediterr. Mar. Sci. 2010, 11, 381. [CrossRef]

161. Day, J.H. Israel South Red Sea Expedition, 1962, Reports no. 7. Some Polychaeta from the Israel South Red Sea Expedition, 1962. Bull. Sea Fish. Res. Stn. Haifa 1965, 38, 15-27.

162. Harmelin, J.G. Contribution à l'étude de l'endofaune des prairies d'Halophila stipulacea de Méditerranée Orientale. Recl. Trav. Stn. Mar. d'Endoume 1969, 45, 305-316.

163. McIntosh, W.C. Report on the Annelida Polychaeta collected by HMS "Challenger" during the years 1873-1876. Reports on the Scientific Results of the Voyage of HMS "Challenger". Zoology 1885, 12, 1-554.

164. Ramos, J.M. Haploscoloplos kerguelensis McIntosh, 1885. Nouvel Orbiniidae en Méditerranée Occidentale. Vie Milieu 1976, $26,1-9$.

165. Claparède, R.-É. Royal College of Physicians of Edinburgh. In Les Annelides Chétopodes du Golfe de Naples; Smithsonian Institution: Washington, DC, USA, 1870; Volume 19, pp. 313-584.

166. Chamberlin, R.V. New polychaetous annelids from Laguna Beach, California. Pomona Coll. J. Entomol. Zool. 1919, $11,1-23$.

167. Kinberg, J. Annulata Nova. Öfversigt Königlich Vetensk. Förhandlingar 1866, 22, 337.

168. Bleidorn, C.; Kruse, I.; Albrecht, S.; Bartolomaeus, T. Mitochondrial sequence data expose the putative cosmopolitan polychaete Scoloplos armiger (Annelida, Orbiniidae) as a species complex. BMC Evol. Biol. 2006, 6, 47. [CrossRef] [PubMed]

169. Verrill, A.E. XVIII. Report upon the Invertebrate Animals of Vineyard Sound and the Adjacent Waters, with an Account of the Physical Characters of the Region. Available online: https:/ / www.biodiversitylibrary.org/bibliography/11688\#/summary (accessed on 18 December 2020).

170. Holte, B.; Gulliksen, B. Common macrofaunal dominant species in the sediments of some north Norwegian and Svalbard glacial fjords. Polar Biol. 1998, 19, 375-382. [CrossRef]

171. Carvalho, S.; Ravara, A.; Quintino, V.; Rodrigues, A. Macrobenthic community characterisation of an estuary from the western coast of Portugal (Sado estuary) prior to dredging operations. Boletín Inst. Español Oceanogr. 2001, 17, 179-190.

172. Belan, T.A. Marine environmental quality assessment using polychaete taxocene characteristics in Vancouver Harbour. Mar. Environ. Res. 2004, 57, 89-101. [CrossRef] 
173. Kraan, C.; Dekinga, A.; Piersma, T. Now an empty mudflat: Past and present benthic abundances in the western Dutch Wadden Sea. Helgol. Mar. Res. 2010, 65, 51-58. [CrossRef]

174. Luttikhuizen, P.C.; Bol, A.; Cardoso, J.F.; Dekker, R. Overlapping distributions of cryptic Scoloplos cf. armiger species in the western Wadden Sea. J. Sea Res. 2011, 66, 231-237. [CrossRef]

175. Faulwetter, S.; Simboura, N.; Katsiaras, N.; Chatzigeorgiou, G.; Arvanitidis, C. Polychaetes of Greece: An updated and annotated checklist. Biodivers. Data J. 2017, 5, e20997. [CrossRef]

176. Kruse, I.; Reise, K. Reproductive isolation between intertidal and subtidal Scoloplos armiger (Polychaeta, Orbiniidae) indicates sibling species in the North Sea. Mar. Biol. 2003, 143, 511-517. [CrossRef]

177. Kruse, I.; Strasser, M.; Thiermann, F. The role of ecological divergence in speciation between intertidal and subtidal Scoloplos armiger (Polychaeta, Orbiniidae). J. Sea Res. 2004, 51, 53-62. [CrossRef]

178. Francoeur, A.A.; Dorgan, K.M. Burrowing Behavior in Mud and Sand of Morphologically Divergent Polychaete Species (Annelida: Orbiniidae). Biol. Bull. 2014, 226, 131-145. [CrossRef] [PubMed]

179. Blake, J.A.; Hilbig, B. Dense infaunal assemblages on the continental slope off Cape Hatteras, North Carolina. Deep. Sea Res. Part II Top. Stud. Oceanogr. 1994, 41, 875-899. [CrossRef]

180. Zhadan, A. Taxonomy of the genus Scoloplos (orbiniidae) in the white, barents and north seas. Зоологический журнал 1998, 77, 177-190.

181. Fauvel, P. Sur l'Aricia foetida, Claparède et ses variétés. Bull. Société Zool. Fr. 1924, 49, 518-528.

182. Hartman, O. Systematic account of some marine invertebrate animals from the deep basins off southern California. Allan Hancock Pac. Exped. 1960, 22, 69-216.

183. Grube, A.E. Beschreibungen neuer oder wenig bekannter Anneliden. Archiv für Naturgeschichte 1855, 21, 81-136. [CrossRef]

184. Day, F.J.H. The polychaet fauna of south africa. part 6. sedentary species dredged off cape coasts with a few new records from the shore. J. Linn. Soc. Lond. Zool. 1961, 44, 463-560. [CrossRef]

185. Southern, R. Polychaeta of the Chilka Lake and also of fresh and brackish waters in other parts of India. Mem. Indian Mus. 1921, 5, 563-659.

186. Giangrande, A.; Fraschetti, S. A population study of Naineris laevigata (Polychaeta, Orbiniidae) in a fluctuating environment (Mediterranean Sea). Sci. Mar. 1995, 59, 39-48.

187. Khan, S.A.; Murugesan, P. Polychaete diversity in Indian estuaries. Indian J. Mar. Sci. 2005, 34, 114-119.

188. Grieshaber, M. Adaptation of the polychaete worm Scoloplos armiger to hypoxic conditions. Mar. Biol. 1988, 99, 215-222. [CrossRef]

189. Linnaeus, C. Systema Naturae per regna tria naturae secundum classes, ordines, genera, species cum characteribus, differentiis, synonymis, locis. Editio decima, reformata. Laurentius Salvius Holmiae 1758, 2, 824.

190. Gustafson, R.G.; Turner, R.D.; Lutz, R.; Vrijenhoek, R.C. A new genus and five new species of mussels (Bivalvia, Mytilidae) from deep-sea sulfide/hydrocarbon seeps in the Gulf of Mexico. Malacologia 1998, 40, 63-112.

191. Hourdez, S.; Schernecke, A.; Fisher, C.R.; Frederick, L.-A. Functional respiratory anatomy of a deep-sea orbiniid polychaete from the Brine Pool NR-1 in the Gulf of Mexico. Invertebr. Biol. 2005, 120, 29-40. [CrossRef]

192. Hourdez, S.; Weber, R.E.; Green, B.N.; Kenney, J.M.; Fisher, C.R. Respiratory adaptations in a deep-sea orbiniid polychaete from Gulf of Mexico brine pool NR-1: Metabolic rates and hemoglobin structure/function relationships. J. Exp. Biol. 2002, 205, 1669-1681.

193. Van Gaest, A.L.; Young, C.M.; Young, J.J.; Helms, A.R.; Arellano, S.M. Physiological and behavioral responses of Bathynerita naticoidea (Gastropoda: Neritidae) and Methanoaricia dendrobranchiata (Polychaeta: Orbiniidae) to hypersaline conditions at a brine pool cold seep. Mar. Ecol. 2007, 28, 199-207. [CrossRef]

194. Will, K.W.; Mishler, B.D.; Wheeler, Q.D. The Perils of DNA Barcoding and the Need for Integrative Taxonomy. Syst. Biol. 2005, 54, 844-851. [CrossRef]

195. Padial, J.M.; Miralles, A.; De La Riva, I.; Vences, M. The integrative future of taxonomy. Front. Zool. 2010, 7, 16. [CrossRef]

196. Giribet, G. Morphology should not be forgotten in the era of genomics-A phylogenetic perspective. Zool. Anz.-A J. Comp. Zool. 2015, 256, 96-103. [CrossRef]

197. Fauvel, P. Annélides Polychètes nouvelles de l'Afrique orientale: 2ième note. Bull. Mus. D'histoire Nat. 1919, 1, 33-39.

198. Borja, A.; Franco, J.; Pérez, V. A Marine Biotic Index to Establish the Ecological Quality of Soft-Bottom Benthos Within European Estuarine and Coastal Environments. Mar. Pollut. Bull. 2000, 40, 1100-1114. [CrossRef]

199. Bigot, L.; Grémare, A.; Amouroux, J.-M.; Frouin, P.; Maire, O.; Gaertner, J.C. Assessment of the ecological quality status of soft-bottoms in Reunion Island (tropical Southwest Indian Ocean) using AZTI marine biotic indices. Mar. Pollut. Bull. 2008, 56, 704-722. [CrossRef] [PubMed]

200. Teixeira, H.; Weisberg, S.B.; Borja, A.; Ranasinghe, J.A.; Cadien, D.B.; Velarde, R.G.; Lovell, L.L.; Pasko, D.; Phillips, C.A.; Montagne, D.E.; et al. Calibration and validation of the AZTI's Marine Biotic Index (AMBI) for Southern California marine bays. Ecol. Indic. 2012, 12, 84-95. [CrossRef]

201. Driscoll, S.K.; McElroy, A.E. Bioaccumulation and metabolism of benzo[A]pyrene in three species of polychaete worms. Environ. Toxicol. Chem. 1996, 15, 1401-1410. [CrossRef]

202. Hartman, O. The littoral marine annelids of the Gulf of Mexico. Publ. Inst. Mar. Sci. Port Aransas Texas 1951, 2, 7-124. 
203. Rakocinski, C.F.; Brown, S.S.; Gaston, G.R.; Heard, R.W.; Walker, W.W.; Summers, J.K. Macrobenthic Responses to Natural and Contaminant-Related Gradients in Northern Gulf of Mexico Estuaries. Ecol. Appl. 1997, 7, 1278. [CrossRef]

204. Elías, R.; Rivero, M.S.; Vallarino, E.A. Sewage impact on the composition and distribution of Polychaeta associated to intertidal mussel beds of the Mar del Plata rocky shore, Argentina. Iheringia. Série Zool. 2003, 93, 309-318. [CrossRef] 